NATIONAL LABORATORY

\title{
Cost Methodology for Biomass Feedstocks: Herbaceous Crops and Agricultural Residues
}

December 2009

Prepared by

Anthony Turhollow

Erin Wilkerson

Shahab Sokhansanj

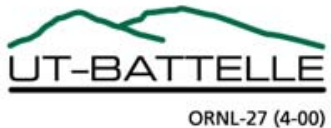




\section{DOCUMENT AVAILABILITY}

Reports produced after January 1, 1996, are generally available free via the U.S. Department of Energy (DOE) Information Bridge.

Web site http://www.osti.gov/bridge

Reports produced before January 1, 1996, may be purchased by members of the public from the following source.

National Technical Information Service

5285 Port Royal Road

Springfield, VA 22161

Telephone 703-605-6000 (1-800-553-6847)

TDD 703-487-4639

Fax 703-605-6900

E-mail info@ntis.gov

Web site http://www.ntis.gov/support/ordernowabout.htm

Reports are available to DOE employees, DOE contractors, Energy Technology Data Exchange (ETDE) representatives, and International Nuclear Information System (INIS) representatives from the following source.

Office of Scientific and Technical Information

P.O. Box 62

Oak Ridge, TN 37831

Telephone 865-576-8401

Fax 865-576-5728

E-mail reports@osti.gov

Web site http://www.osti.gov/contact.html

This report was prepared as an account of work sponsored by an agency of the United States Government. Neither the United States Government nor any agency thereof, nor any of their employees, makes any warranty, express or implied, or assumes any legal liability or responsibility for the accuracy, completeness, or usefulness of any information, apparatus, product, or process disclosed, or represents that its use would not infringe privately owned rights. Reference herein to any specific commercial product, process, or service by trade name, trademark, manufacturer, or otherwise, does not necessarily constitute or imply its endorsement, recommendation, or favoring by the United States Government or any agency thereof. The views and opinions of authors expressed herein do not necessarily state or reflect those of the United States Government or any agency thereof. 
Bioenergy Resource and Engineering Systems

Environmental Sciences Division

\title{
COST METHODOLOGY FOR BIOMASS FEESTOCKS: HERBACEOUS CROPS AND AGRICULTURAL RESIDUES
}

\author{
Anthony F. Turhollow \\ Erin G. Wilkerson \\ Shahab Sokhansanj
}

Date Published: December 2009

Prepared by

OAK RIDGE NATIONAL LABORATORY

Oak Ridge, Tennessee 37831-6283

managed by

UT-BATTELLE, LLC

for the

U.S. DEPARTMENT OF ENERGY

under contract DE-AC05-00OR22725 



\section{CONTENTS}

LIST OF TABLES

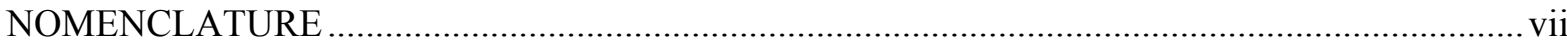

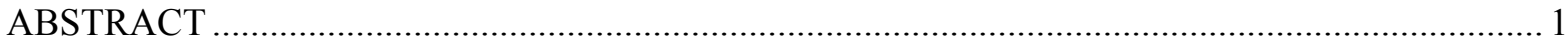

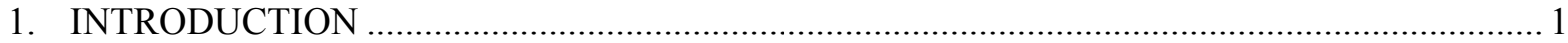

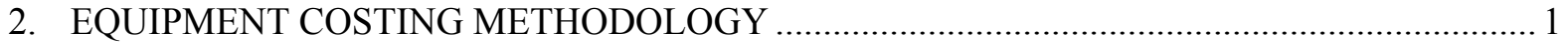

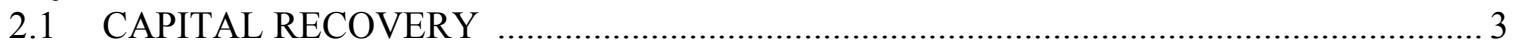

2.1.1 Integrated Biomass Supply Analysis and Logistics Model (IBSAL)......................... 6

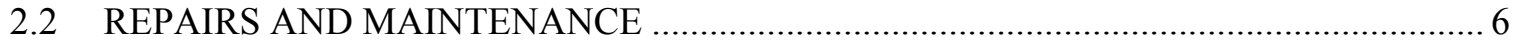

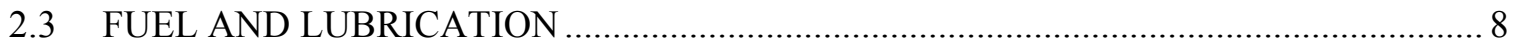

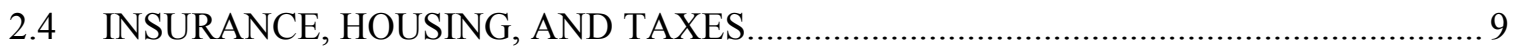

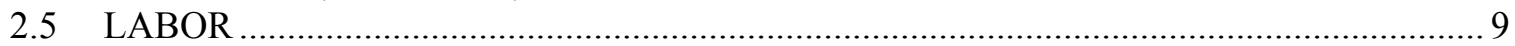

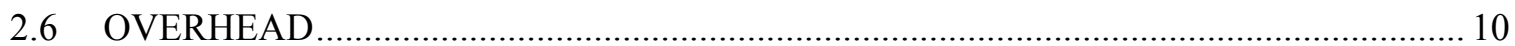

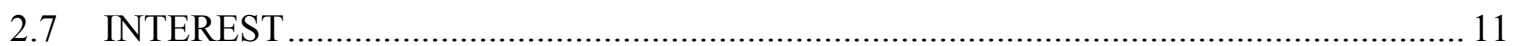

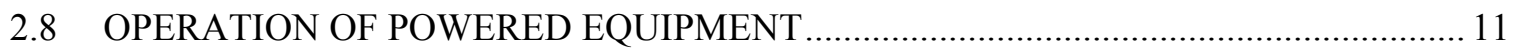

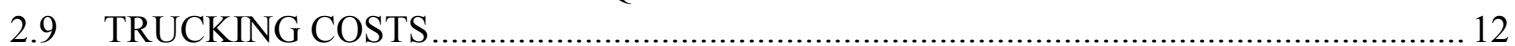

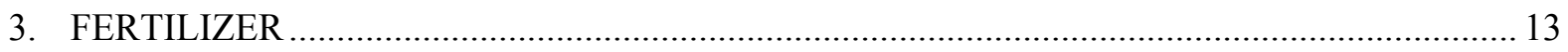

4. MACHINERY PERFORMANCE IN HANDLING AND PROCESSING BIOMASS ................. 13

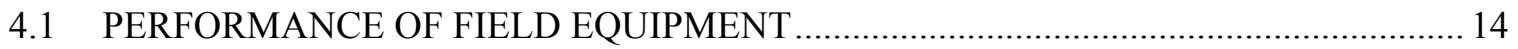

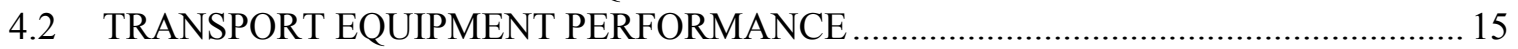

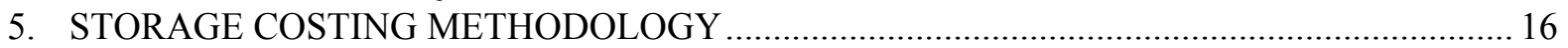

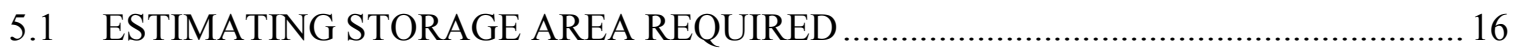

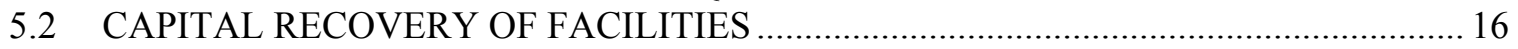

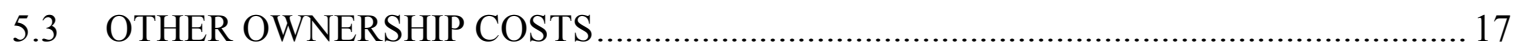

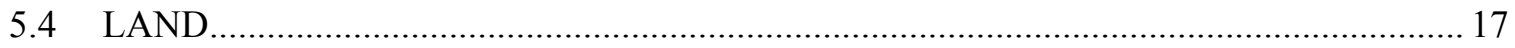

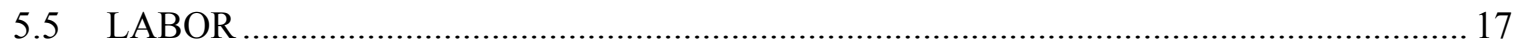

5.6 IMPACTS OF DRY MATTER LOSS ON COST ESTIMATES …................................. 18

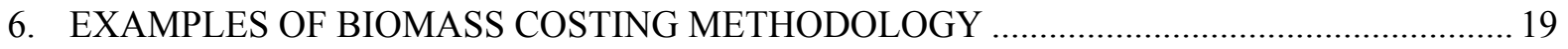

6.1 HARVESTING AN EXISTING PASTURE AS A SILAGE-TYPE CROP ...................... 19

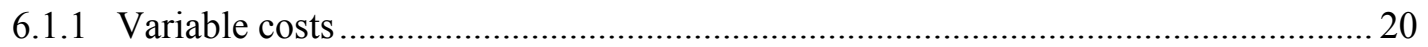

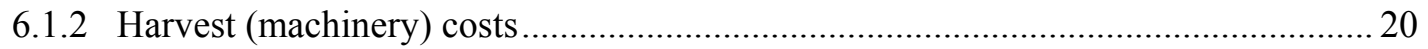

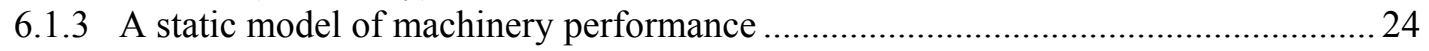

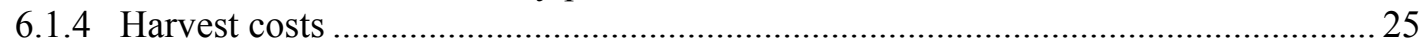

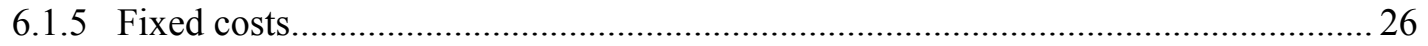

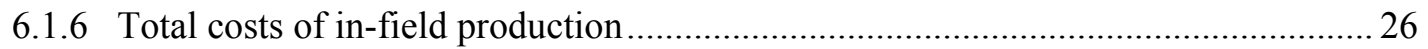

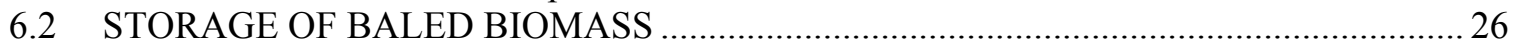

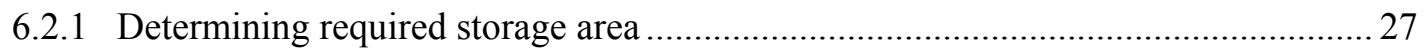

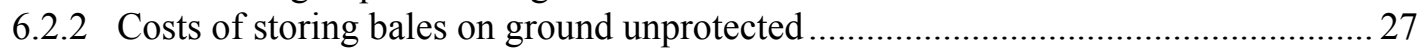

6.2.3 Costs for storing bales outside on gravel pad, covered with tarp ............................ 27

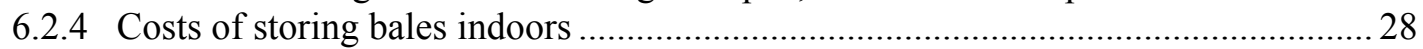

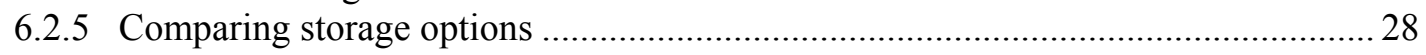

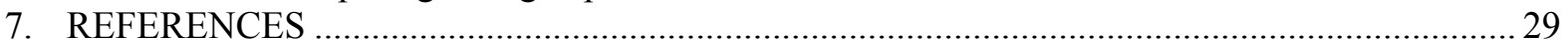

Appendix A: Page numbers for references to old and New versions of AAEA Cost and

Commodity Returns Estimation Handbook.....

A-1 



\section{LIST OF TABLES}

Table

2.1 Index of prices paid by farmers for production items and farm machinery, $1991=$

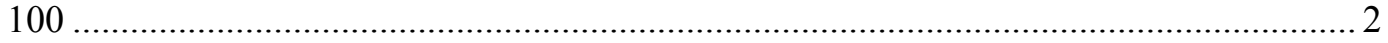

2.2 Pre-1997 equations used by the ASAE to calculate remaining values ............................ 5

$2.3 \quad$ Coefficients for the ASABE remaining value equation .............................................. 5

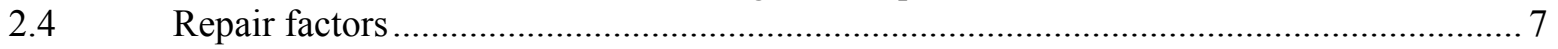

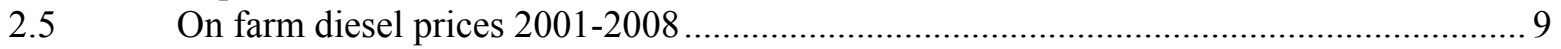

2.6 Wage rates for all hired workers in the United States.............................................. 10

2.7 Overhead rates recommended by the AAEA for corn, soybeans, and alfalfa................... 11

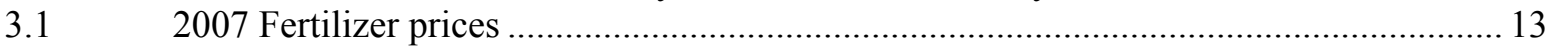

4.1 Field efficiencies and speeds of agricultural equipment ............................................... 14

5.1 Estimated investment costs and useful lived for components of biomass storage

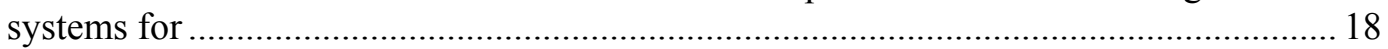

Estimated dry matter loss in round bales of hay for various storage methods................... 19

6.1 Summary of production costs for silage harvest example ............................................ 20

6.2 Hourly costs of implements used in silage harvest example........................................... 21

6.3 Performance of mowing and pickup operations for [tall fescue] silage harvest

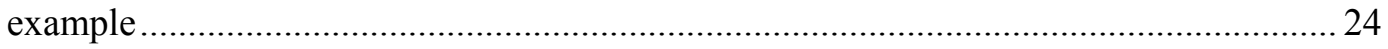

6.4 Performance of the combined pickup and transport to field edge operation in silage

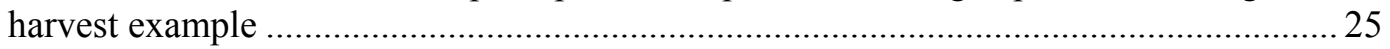

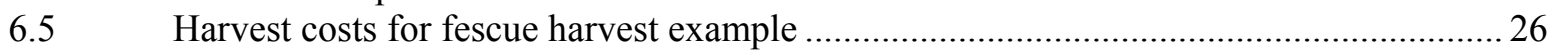

6.6 Costs of three storage options for switchgrass bales.................................................... 29 

$\mathrm{A}=$ land area covered, ha (ac)

\section{NOMENCLATURE}

$\mathrm{C}_{1}, \mathrm{C}_{2}=$ coefficient for unit consistency

$\mathrm{c}_{1}, \mathrm{c}_{2}, \mathrm{c}_{3}=$ coefficients for various equipment types

Cap = capital cost (depreciation plus interest), $\$ / \mathrm{h}$

$\mathrm{C}_{\mathrm{o}}=$ ownership cost of storage site, $\$ /$ dry $\mathrm{Mg}$ ( $\$ /$ dry ton)

$\mathrm{C}_{\mathrm{rm}}=$ accumulated repair and maintenance cost, $\$$

$\mathrm{C}_{\mathrm{rm} \text { hourly }}=$ average hourly repair and maintenance cost, $\$$

$\mathrm{C}_{\mathrm{rm} \_ \text {life }}=$ lifetime repair and maintenance costs, fraction of list price (Table 1.4)

$\mathrm{C}_{\mathrm{rm} \text { total }}=$ total repair and maintenance costs over a machine's useful life, $\$$

$\mathrm{C}_{\mathrm{s}}=$ cost to store biomass, $\$ /$ dry $\mathrm{Mg}$ ( $\$ /$ dry ton)

$\mathrm{DML}=$ dry matter loss, decimal

$\mathrm{dSV}=$ discounted salvage value, $\$$

$\mathrm{e}=$ constant $(<1)$ to account for turns and obstacles that increase transport time, or machine efficiency

$\mathrm{F}=$ average fuel use, liters $(\mathrm{L})$ of diesel $/ \mathrm{h}$ [gallons (gal) of diesel $/ \mathrm{h}$ ]

$\mathrm{F}_{\text {pto }}=$ specific fuel consumption, $\mathrm{L} / \mathrm{kW} / \mathrm{h}(\mathrm{gal} / \mathrm{hp} / \mathrm{h})$

$\mathrm{h}=$ machine accumulated use, $\mathrm{h}$

$\mathrm{h}_{\mathrm{a}}=$ machine annual use, $\mathrm{h}$

$\mathrm{h}_{1}=$ machine lifetime use, $\mathrm{h}$

$\mathrm{i}=$ interest (discount) rate, fraction

$\mathrm{k}=$ coefficient $(<1)$ to account for incomplete loading of the truck

$\mathrm{LP}=$ list price, $\$$

$\mathrm{M}_{\mathrm{w}}=$ wet basis moisture content, decimal

$\mathrm{n}=$ life of investment or useful machine life, $\mathrm{yr}$

$\mathrm{PP}=$ purchase price or initial investment, $\$$

$\mathrm{P}_{\text {pto }}=$ rated PTO power, $\mathrm{kW}(\mathrm{hp})$

$\mathrm{Q}=$ amount biomass processed per hour, $\mathrm{Mg} / \mathrm{h}$ (ton $/ \mathrm{h}$ )

$\mathrm{q}=$ unit throughput, dry $\mathrm{Mg} / \mathrm{h}$ (dry ton $/ \mathrm{h}$ )

$\mathrm{RF}_{1}, \mathrm{RF}_{2}=$ repair and maintenance factors

$\mathrm{RV}_{\mathrm{n}}=$ remaining value at end of year $\mathrm{n}, \%$ list price

$\mathrm{s}=$ equipment speed, $\mathrm{km} / \mathrm{h}(\mathrm{mi} / \mathrm{h})$

$\mathrm{SV}=$ salvage value, $\$$

$\mathrm{t}=$ time required for operation to be completed, $\mathrm{h}$

$t_{\text {haul }}, t_{\text {return }}=$ forward and return time of the transporter per load, respectively, $h$

$t_{l d}, t_{\text {uld }}=$ loading and unloading times per load, respectively, $h$

$t_{m}=$ time in field for operations other than travel (e.g. time to tie or to wrap bale)

$t_{\text {tr }}=$ total transport time per load, $h$

$\mathrm{V}=$ volume of the container, $\mathrm{m}^{3}\left(\mathrm{ft}^{3}\right)$

$\mathrm{w}=$ cut width or effective width of rake, $\mathrm{m}(\mathrm{ft})$

$\mathrm{W}_{\mathrm{b}}=$ transporter capacity, wet $\mathrm{Mg}$ (ton)

$\mathrm{W}_{\mathrm{t}}=$ rate of in-field transportation in $\mathrm{Mg} / \mathrm{h}(\mathrm{ton} / \mathrm{h})$

$\mathrm{X}=$ fraction of the maximum PTO used for a particular operation, fraction

$\mathrm{Y}=$ yield, $\mathrm{Mg} / \mathrm{ha}$ (ton/ac) or net yield, dry $\mathrm{Mg} / \mathrm{ha}$ (dry ton/ac)

$\rho_{\mathrm{b}}=$ bulk density of the biomass, $\mathrm{kg} / \mathrm{m}^{3}\left(\mathrm{lb} / \mathrm{ft}^{3}\right)$

$\rho_{\mathrm{b}}=$ moist bulk density, $\mathrm{kg} / \mathrm{m}^{3}\left(\mathrm{lb} / \mathrm{ft}^{3}\right)$

$\rho_{\mathrm{d}}=$ dry bulk density, $\mathrm{kg} / \mathrm{m}^{3}\left(\mathrm{lb} / \mathrm{ft}^{3}\right)$

$\rho_{\mathrm{w}}=$ density of water, $\mathrm{kg} / \mathrm{m}^{3}\left(\mathrm{lb} / \mathrm{ft}^{3}\right)$

$\mathrm{W}_{\text {store }}=$ mass of biomass in storage, dry $\mathrm{Mg}$ (dry ton) 



\begin{abstract}
This report describes a set of procedures and assumptions used to estimate production and logistics costs of bioenergy feedstocks from herbaceous crops and agricultural residues. The engineeringeconomic analysis discussed here is based on methodologies developed by the American Society of Agricultural and Biological Engineers (ASABE) and the American Agricultural Economics Association (AAEA). An engineering-economic analysis approach was chosen due to lack of historical cost data for bioenergy feedstocks. Instead, costs are calculated using assumptions for equipment performance, input prices, and yield data derived from equipment manufacturers, research literature, and/or standards. Cost estimates account for fixed and variable costs. Several examples of this costing methodology used to estimate feedstock logistics costs are included at the end of this report.
\end{abstract}

\title{
1. INTRODUCTION
}

A question that often arises with regard to biomass resources is: How much does it cost? Estimates of costs from various sources may have very different assumptions regarding, interest rates, labor costs, fuel prices, etc. The objective of this report is to describe an appropriate standardized methodology for estimating the delivered cost of biomass crops that is acceptable to industry, academia, and government.

There are two basic methods for developing costs for crops. One is an engineering-economic approach where engineering parameters (e.g., machine speed, width) are combined with economic parameters (e.g., price of diesel) to determine the cost of producing a crop. The other is an econometric approach which relates parameters to the cost of production via an econometrically estimated equation based on historical data. For biomass crops we have limited historical data on production, as many of these crops are not currently commercially grown, are only grown on a limited scale, or have only a brief history of production. Choosing the engineering-economic approach allows estimation of costs of production for biomass crops based on assumed equipment characteristics, input prices, and estimated crop yields.

Two engineering-economic approaches to costing are presented by the American Society of Agricultural and Biological Engineers (ASABE 2006b) and the American Agricultural Economics Association (AAEA 2000). These two approaches differ slightly, but the AAEA method incorporates much from the ASABE method.

There is more to developing the methodology than just agreeing on how to perform calculations. The second, and probably more difficult part, is determining assumptions and parameter values. Calculating the cost to harvest, handle, transport, and store biomass involves:

1. Determining appropriate assumptions of the costs of machinery and buildings, and

2. Estimating the performance, or efficiency, of machinery in handling and processing biomass.

The cost of machinery and buildings is expressed as fixed costs and variable costs. Labor and variable costs are expressed in $\$ / h$. Fixed cost is an annual cost that includes annualized capital cost plus other fixed costs such as machinery storage, taxes, and insurance. For an assumed number of working hours per year for machinery, the annual cost is expressed in $\$ / \mathrm{h}$ as well.

The costs associated with the performance of machinery are expressed in $\$ / \mathrm{Mg}(\$ /$ ton $)$, $\$ /$ item, or $\$ /$ ha $(\$ /$ ac). For example, we may express mowing a field in $\$$ ha $(\$ /$ acre), baling in $\$ /$ bale, and grinding the biomass in $\$ / \mathrm{Mg}(\$ /$ ton). These costs are calculated after the machine has performed a function on the product or on the land. For calculating these costs we need operating characteristics of the machines such as speed, field efficiency, width of operation, and/or throughput.

\section{EQUIPMENT COSTING METHODOLOGY}

The focus of this section is to describe a procedure for estimating farm equipment costs. Costs for fertilizer, a major input incurred in the production of biomass feedstocks will be discussed in Section 3. 
Estimation of storage costs will be addressed in Section 5. For cropping and transport operations to be profitable, the costs listed below must be recovered.

- Capital recovery (depreciation and interest)

- Repairs and maintenance

- Fuel and lubrication

- Insurance, housing, and taxes

- Labor

- Overhead

- Interest

In this document, all costing is done in constant dollars (i.e. all costs are adjusted to a base year, 2007), as opposed to [mixed year] nominal dollars. Estimated prices of production inputs are adjusted to the chosen base year using the "Index of prices paid by farmers" (Table 2.1) published monthly in the U.S. Department of Agriculture's Agricultural Prices report. An exception is farm equipment where we use prices paid by farmers for farm machinery (e.g., see USDA/NASS 2008a).

To adjust price for inflation, one can multiply the purchase price by a ratio of the index of the year of analysis (this paper uses 2007 dollars) divided by the year in which the purchase price is given. As an example, consider a tractor that cost $\$ 120,000$ in 2006. In 2007 dollars the cost would be $\$ 124,615$ $(\$ 120,000 * 189 / 182)$ [189 is the value of the machinery index in 2007 and 182 is the value of the machinery index in 2006 (the year of the cost data).]

Table 2.1. Index of prices paid by farmers for production items and farm machinery, $1991=100$

\begin{tabular}{|c|c|c|}
\hline Year & Production Price Index & Machinery Price Index \\
\hline 2008 & 187 & 206 \\
\hline 2007 & 160 & 191 \\
\hline 2006 & 148 & 182 \\
\hline 2005 & 140 & 173 \\
\hline 2004 & 131 & 162 \\
\hline 2003 & 124 & 151 \\
\hline 2002 & 119 & 148 \\
\hline 2001 & 120 & 143 \\
\hline 2000 & 116 & 139 \\
\hline 1999 & 111 & 135 \\
\hline 1998 & 113 & 132 \\
\hline 1997 & 119 & 128 \\
\hline 1996 & 115 & 125 \\
\hline 1995 & 108 & 120 \\
\hline 1994 & 106 & 113 \\
\hline 1993 & 104 & 107 \\
\hline 1992 & 101 & 104 \\
\hline 1991 & 100 & 100 \\
\hline 1990 & 99 & 96 \\
\hline Sources: USDA/NASS $(2000,2008 a, 2009)$ & \\
\hline & & \\
\hline
\end{tabular}




\subsection{CAPITAL RECOVERY}

ASABE lists two different methods for calculating ownership cost: 1) calculating depreciation and interest separately [section 6.2.4 of ASAE EP496.3 FEB2006 (ASABE 2006b)] [The AAEA (2000) refers to this as the "traditional method" (p.6-17).] and 2) the capital recovery method of calculating depreciation and interest on the value to be depreciated and calculating interest on the salvage value [section 6.2.2 of ASAE EP496.3 FEB2006 (ASABE 2006b)]. For reference, both procedures are described below. However, the second method, capital recovery, is recommended based on the Commodity Cost and Returns Estimation Handbook published by the American Agricultural Economics Association (AAEA 2000) and will be used in proceeding analyses of this report.

The traditional method of estimating ownership costs by calculating straight-line depreciation and interest separately is given by equation $2-1$.

$$
\mathrm{Cap}=\frac{(\mathrm{PP}-\mathrm{dSV})}{\mathrm{h}_{1}}+\frac{\mathrm{i}(\mathrm{PP}+\mathrm{dSV})}{(2)\left(\mathrm{h}_{\mathrm{a}}\right)}
$$

where $C a p=$ capital cost (depreciation plus interest), $\$ / \mathrm{h}$

$\mathrm{PP}=$ purchase price, $\$$

$\mathrm{dSV}=$ discounted salvage value, $\$$

$\mathrm{dSV}=\frac{\mathrm{SV}}{(1+\mathrm{i})^{\mathrm{n}}}$

$\mathrm{SV}=$ salvage value, $\$$

$\mathrm{h}_{\mathrm{a}}=$ annual use, $\mathrm{h}$

$\mathrm{h}_{\mathrm{l}}=$ lifetime use, $\mathrm{h}$

$\mathrm{i}=$ interest (discount) rate (assumed to be $6 \%$ in our examples), fraction

$\mathrm{n}=$ useful life, $\mathrm{yr}$

Equation 2-1 is a variation of the equation in section 6.2.4 of the ASAE EP496.3. SV in section 6.2.4 is a fraction defined by salvage value divided by the purchase price.

The capital recovery method (sometimes called an annuity cost) includes the annual costs of depreciation and interest in a single equation $\left(2-3^{1}\right)$. The AAEA recommends this method for calculating ownership costs saying it is well-suited to including other costs such as maintenance in annual cost estimation.

$$
\mathrm{Cap}=\frac{(\mathrm{PP}-\mathrm{dSV}) * \frac{\mathrm{i}}{1-(1+\mathrm{i})^{-\mathrm{n}}}+\mathrm{dSV} *_{\mathrm{i}}}{\mathrm{h}_{\mathrm{a}}}
$$

where Cap $=$ capital cost, $\$ / \mathrm{h}$

$\mathrm{n}=$ useful life, $\mathrm{yr}$

$\mathrm{PP}=$ purchase price, $\$$

$\mathrm{SV}=$ salvage value, $\$$

$\mathrm{dSV}=$ discounted salvage value, $\$$

$h_{a}=$ machine annual use, $h$

$\mathrm{h}_{1}=$ machine lifetime use, $\mathrm{h}$

$\mathrm{i}=$ interest (discount) rate, fraction

\footnotetext{
${ }^{1}$ In equation $2-3 \mathrm{i} /\left[\left(1-(1+\mathrm{i})^{-\mathrm{n}}\right]\right.$ is equivalent to $\mathrm{i}(1+\mathrm{i})^{\mathrm{n}} /\left[(1+\mathrm{i})^{\mathrm{n}}-1\right]$
} 
The authors of this report suggest using the capital recovery method (equation 2-3) with the discounted salvage value as recommended by the AAEA (2000).

Note that list price (LP) is different from purchase price (PP). Purchase price is used to calculate capital recovery costs. The AAEA indicates that a rough estimation for the difference between purchase price and list price is $15 \%$ [p. 6- $8^{2}$ AAEA (2000)]. But, in an example (p. 14-11), the AAEA assumed that the list price was only $10 \%$ more than the purchase price (i.e. purchase price was $90.9 \%$ of list price). For the calculations in this report, it is assumed that purchase price is $90 \%$ of list price, a conservative estimate.

Consider the following example to illustrate the differences between the traditional method of calculating ownership costs and the capital recovery method. Let annual use $\left(h_{a}\right)$ be 1000 hours and lifetime use 12,000 hours. Therefore $n=h_{1} / h_{a}=12$ years. The purchase price is $\$ 90,000$ and the salvage value is $\$ 20,000$. Assume an interest rate of $6 \%$. Because the salvage value is received in the future, it should be discounted [see p. 14-17 ${ }^{1}$, AAEA (2000)]. The discounted salvage value (dSV) calculated using equation 2-2 is $\$ 9,939$.

First, calculate the hourly ownership cost using the traditional method (equation 2-1).

$$
\mathrm{Cap}=\frac{(\mathrm{PP}-\mathrm{dSV})}{\mathrm{h}_{1}}+\frac{\mathrm{i}(\mathrm{PP}+\mathrm{dSV})}{(2)\left(\mathrm{h}_{\mathrm{a}}\right)}=\frac{(\$ 90,000-\$ 9,939)}{12,000}+\frac{0.06(\$ 90,000+\$ 9,939)}{(2)(1,000)}=\$ 9.67 / \mathrm{h}
$$

Then, use the capital recovery method (equation 2-3) to calculate hourly ownership cost.

$$
\mathrm{Cap}=\frac{(\mathrm{PP}-\mathrm{dSV}) * \frac{\mathrm{i}}{1-(1+\mathrm{i})^{-\mathrm{n}}}+\mathrm{dSV} * \mathrm{i}}{\mathrm{h}_{\mathrm{a}}}=\frac{(\$ 90,000-\$ 9,939) * \frac{0.06}{1-(1+0.06)^{-12}}+\$ 9,939 * 0.06}{1,000}=\$ 10.15 / \mathrm{h}
$$

If salvage value, rather than discounted salvage value, is used, the traditional method gives $\$ 9.13 / \mathrm{h}$ and the capital recovery method gives $\$ 9.55 / \mathrm{h}$.

Salvage value must be computed to determine interest and depreciation. Salvage value is the remaining value at the end of the unit's useful life. For many years ASABE used the data in Table 2.2 to estimate remaining (salvage) value. ASABE revised these equations in 1997 and used Cross and Perry $(1995,1996)$ as one source for their data [ASABE D497.4 Table 4 (ASABE 2006a)]. The revised coefficients (Table 2.3) are used in the following ASABE equation:

$$
\mathrm{RV}_{\mathrm{n}}=100\left(\mathrm{c}_{1}-\mathrm{c}_{2} \mathrm{n}^{0.5}-\mathrm{c}_{3} \mathrm{~h}_{\mathrm{a}}^{0.5}\right)^{2}
$$

where $\mathrm{RV}_{\mathrm{n}}=$ remaining value at end of year $\mathrm{n}, \%$ list price

$\mathrm{c}_{1}, \mathrm{c}_{2}, \mathrm{c}_{3}=$ Coefficients for various equipment types (Table 2.3)

$h_{a}=$ average annual use, $h$

The AAEA (pp. 6-7 to 6-11) recommends estimating remaining value using equation 2-4 and the coefficients in Table 2.3 (AAEA 2000 and ASABE 2006a). (The numbers in AAEA are to four decimal places while in ASABE are to three decimal places.) The AAEA states that where there is a good match in the machine types to those listed in Table 2.3, those should be used. Where there is not a good match,

2 The AAEA revised its Commodity Costs and Returns Estimation Handbook in 2000. The revisions appear to be minor. However, the pagination between the two versions is slightly different. See Appendix A of this document for appropriate page numbers for references from the 1997 version 
the old ASABE equations (Table 2.2) can be used. Interestingly, AAEA states that mixing the two sets of equations is probably not a good idea, but they do it in their examples [p. 14-17 AAEA (2000)].

Table 2.2. Pre-1997 equations used by the ASAE to calculate remaining values. AAEA recommends using these values when coefficients for equation 2-4 are not available for a particular type of equipment.

\begin{tabular}{|l|c|}
\hline \multicolumn{1}{|c|}{ Equipment class } & $\begin{array}{c}\text { Remaining value (\% list price) } \\
\text { as of end of year n }\end{array}$ \\
\hline Tractors & $68(0.920)^{\mathrm{n}}$ \\
\hline Combines, cotton pickers, self-propelled windrowers & $64(0.885)^{\mathrm{n}}$ \\
\hline Balers, forage harvesters, blowers, self-propelled sprayers & $56(0.885)^{\mathrm{n}}$ \\
\hline All other field machines & $60(0.885)^{\mathrm{n}}$ \\
\hline Source: AAEA (2000), ASAE (2001) \\
\hline
\end{tabular}

Table 2.3. Coefficients for the ASABE remaining value equation

\begin{tabular}{|l|c|c|c|}
\hline \multicolumn{1}{|c|}{ Equipment type } & $\mathbf{c}_{\boldsymbol{1}}$ & $\mathbf{c}_{\mathbf{2}}$ & $\mathbf{c}_{\boldsymbol{3}}$ \\
\hline 22-59 $\mathrm{kW}(30-79 \mathrm{hp})$ tractors & 0.9809 & 0.0934 & 0.0058 \\
\hline $60-112 \mathrm{~kW}(80-150 \mathrm{hp})$ tractors & 0.9421 & 0.0997 & 0.0008 \\
\hline $112+\mathrm{kW}(150+\mathrm{hp})$ tractors & 0.9756 & 0.1187 & 0.0019 \\
\hline Mowers & 0.7557 & 0.0672 & - \\
\hline Balers & 0.8521 & 0.1014 & - \\
\hline Combines & 1.1318 & 0.1645 & 0.0079 \\
\hline Swathers and all other harvest equipment & 0.7911 & 0.0913 & - \\
\hline Plows & 0.7382 & 0.0510 & - \\
\hline Disks and all other tillage equipment & 0.8906 & 0.1095 & - \\
\hline Planters & 0.8826 & 0.0778 & - \\
\hline Manure spreaders and other miscellaneous equipment & 0.9427 & 0.1111 & - \\
\hline Skid-steer loaders and all other vehicles & 0.7858 & 0.0629 & 0.0033 \\
\hline Source: AAEA (2000) Table 6.4 & & \\
\hline
\end{tabular}

Note that only powered equipment has a coefficient $\left(\mathrm{C}_{3}\right)$ on hours of annual use. In the revised ASABE equation (2-4), remaining values for windrowers and forage harvesters are calculated using the "swathers and all other harvest equipment category." For telescopic handlers, we use the "skid-steer loaders and all other vehicles category" and for wagons use the "manure spreaders and all other miscellaneous equipment category." The AAEA recommends using the revised remaining value from AAEA (2000) or ASABE (2006a) [p. 396, Table 4, ASABE (2006a); p. 6-11, Table 6.4, AAEA (2000)]. As an example, consider a tractor that has a useful life of 12 years and average annual use of 1000 hours. The old (Table 2.2) and revised (equation 2-4) remaining value formulas give the following as a fraction of list price:

$$
\begin{aligned}
& 22-59 \mathrm{~kW}(30-79 \mathrm{hp}) \\
& 60-112 \mathrm{~kW}(80-150 \mathrm{hp}) \\
& 112+\mathrm{kW}(150+\mathrm{hp})
\end{aligned}
$$

old: 0.25001

old: 0.25001

old: 0.25001 revised: 0.22462

revised: 0.32653

revised: 0.25435 
For a round baler with useful life of 6 years and annual use of 250 hours, the old salvage value (as a function of list price) would be 0.269 and the revised estimated value would be 0.360 . The revised ASABE (Cross and Perry based) method (equation 2-4, table 2-3) is recommended for determining salvage value where equipment types are not listed in the revised method, use the old (pre-1997) ASABE method (Table 1.2).

\subsubsection{Integrated Biomass Supply Analysis and Logistics Model (IBSAL)}

The Oak Ridge National Laboratory (ORNL) has developed a dynamic simulation program, the Integrated Biomass Supply Analysis and Logistics (IBSAL) model, to improve the accuracy of estimating equipment needs for a biomass supply chain (Sokhansanj et al. 2008). The model can be used to determine the number and size of equipment needed for a biomass supply chain. To make this determination, variable and fixed costs for equipment must be estimated so the model can minimize costs. A clear delineation between fixed and variable costs is important within the model. For the IBSAL model, interest $(\$ / y r)$ and depreciation $(\$ / h)$ are calculated separately.

Capital cost (depreciation and interest) is a fixed cost. However, in the ASABE costing methodology, equipment life (h) is considered predetermined and depreciation becomes a variable cost by definition. [A variable cost is a cost that varies by hours of use. For equipment with a fixed number of hours of life, depreciation varies by hours of use and is thus a variable cost.] Interest cost remains a fixed cost and is based on the average of initial cost (purchase price) plus discounted salvage value. [Note that the interest cost will vary slightly with hours of use per year because the salvage value and discounted salvage value will change.] If one calculates depreciation (on a straight-line basis) and interest (on the average value), the sum of these two is less than when the two are calculated together using equation 2-3.

To illustrate the effect of annual hours of use on capital recovery, consider an 119kW (160 hp) tractor with a purchase price of $\$ 106,909$. The interest rate is assumed to be $6 \%$. If the number of annual hours of use is 1,000 , the interest is $\$ 3,657 /$ year and the salvage value is $\$ 30,137$. However, if the annual hours of use are 500, the interest is $\$ 3,315 /$ year and the salvage value is $\$ 14,596$. The interest is calculated using the traditional formula (the second half of equation $\left.2-1: \mathrm{i}(\mathrm{PP}+\mathrm{dSV}) / 2 \mathrm{~h}_{\mathrm{a}}\right)$ assuming that the residual [of the combined capital cost calculation (equation 2-4) minus the interest] is the depreciation. [Note that for use in IBSAL itself, $\mathrm{i}(\mathrm{PP}+\mathrm{dSV}) / 2$ is not divided by $\mathrm{h}_{\mathrm{a}}$ because one is not interested in the hourly cost, but in the annual cost.]

\subsection{REPAIRS AND MAINTENANCE}

Repair and maintenance costs can be calculated by equation 2-5 from ASABE (2006b):

$$
\mathrm{C}_{\mathrm{rm}}=\left(\mathrm{RF}_{1}\right) \mathrm{LP}\left(\frac{\mathrm{h}}{1000}\right)^{\mathrm{RF}_{2}}
$$

where $\mathrm{C}_{\mathrm{rm}}=$ accumulated repair and maintenance cost, $\$$

$\mathrm{LP}=$ list price, $\$$

$\mathrm{h}=$ accumulated use, $\mathrm{h}$

$\mathrm{RF}_{1}, \mathrm{RF}_{2}=$ repair and maintenance factors

The repair and maintenance factors, $\mathrm{RF}_{1}$ and $\mathrm{RF}_{2}$, can be obtained from Table 3 of ASABE (2006a)

or Table 5.2 of AAEA (2000) (Note: these two tables, 3 and 5.2 are identical.) When $\mathrm{h}$ is set to the hours of useful life, then accumulated repairs equal lifetime repairs also listed in tables 3 and 5.2 mentioned above (listed here in Table 2.4). We assume that equipment is used for its useful lifetime. $R_{1}$ and $R_{2}$ 
distribute repair costs over time, spreading more cost to later in a machine's life. With this assumption the formula can be simplified to:

$$
\mathrm{C}_{\mathrm{rm}_{-} \text {total }}=\mathrm{C}_{\mathrm{rm}_{-} \text {life }} * \mathrm{LP}
$$

where $\mathrm{C}_{\mathrm{rm} \_ \text {total }}=$ total repair and maintenance costs over a machine's useful life, $\$$

$\mathrm{C}_{\mathrm{rm} \_ \text {life }}=$ lifetime repair and maintenance costs, fraction of list price (Table 1.4)

$$
\mathrm{C}_{\mathrm{rm}_{-} \text {hourly }}=\frac{\mathrm{C}_{\mathrm{rm} \_ \text {life }} * \mathrm{LP}}{\mathrm{h}}
$$

where $\mathrm{C}_{\mathrm{rm} \_ \text {hourly }}=$ average hourly repair and maintenance cost, $\$$

$\mathrm{h}=$ useful life, $\mathrm{h}($ Table 2.4$)$

Table 2.4. Repair factors

\begin{tabular}{|l|c|c|c|c|}
\hline \multirow{2}{*}{ Machine } & Useful & Total life R\&M cost & \multicolumn{2}{c|}{ Repair factors } \\
\cline { 4 - 5 } & Life (h) & (\% of list price) & RF1 & RF2 \\
\hline Tractor (2-wheel drive) & 12,000 & 100 & 0.007 & 2.0 \\
\hline Tractor (4-wheel drive) & 16,000 & 80 & 0.003 & 2.0 \\
\hline Combine (self-propelled) & 2,000 & 40 & 0.04 & 2.1 \\
\hline Mower & 2,000 & 150 & 0.46 & 1.7 \\
\hline Mower (rotary) & 2,000 & 175 & 0.44 & 2.0 \\
\hline Mower-conditioner & 2,500 & 80 & 0.18 & 1.6 \\
\hline Mower-conditioner (rotary) & 2,500 & 100 & 0.16 & 2.0 \\
\hline Windrower (self-propelled) & 3,000 & 55 & 0.06 & 2.0 \\
\hline Rake (side-delivery) & 2,500 & 60 & 0.17 & 1.4 \\
\hline Baler (large rectangular) & 3,000 & 75 & 0.10 & 1.8 \\
\hline Baler (large round) & 1,500 & 90 & 0.43 & 1.8 \\
\hline Forage harvester & 2,500 & 65 & 0.15 & 1.6 \\
\hline Forage harvester (self- propelled) & 4,000 & 50 & 0.03 & 2.0 \\
\hline Fertilizer spreader & 1,200 & 80 & 0.63 & 1.3 \\
\hline Boom-type sprayer & 1,500 & 70 & 0.41 & 1.3 \\
\hline Forage blower & 1,500 & 45 & 0.22 & 1.8 \\
\hline Forage wagon & 2,000 & 50 & 0.16 & 1.6 \\
\hline Wagon & 3,000 & 80 & 0.19 & 1.3 \\
\hline Source: (ASABE 2006a) & & & & \\
\hline
\end{tabular}

The AAEA recommends using this simplified formula and averaging repair and maintenance costs over time as described above. As an example, consider a tractor that has a useful life of 12,000 hours and a list price of $\$ 90,000$. From Table 2-4 the total life repair and maintenance cost is $100 \%$ of the list price and the repair factors, $\mathrm{RF}_{1}$ and $\mathrm{RF}_{2}$ are 0.007 and 2.0, respectively. Using equation 2-5, the hourly repair and maintenance cost is: 


$$
\mathrm{C}_{\mathrm{rm}_{\text {h hourly }}}=\frac{\left(\mathrm{RF}_{1}\right) \mathrm{LP}\left(\frac{\mathrm{h}}{1000}\right)^{\mathrm{RF}_{2}}}{\mathrm{~h}}=\frac{(0.007) \$ 90,000\left(\frac{12,000}{1000}\right)^{2}}{12,000}=\$ 7.56 / \mathrm{hr}
$$

Using the simplified formula,

$$
\mathrm{C}_{\mathrm{rm}_{-} \text {hourly }}=\frac{\mathrm{C}_{\mathrm{rm}_{-} \text {life }} * \mathrm{LP}}{\mathrm{h}}=\frac{1.0 * \$ 90,000}{12,000}=\$ 7.50 / \mathrm{hr}
$$

The answers would both be $\$ 7.50 / \mathrm{h}$ if $\mathrm{RF}_{1}$ were more precisely specified as 0.006944 . If it is estimated that the machine will be used less than the lifetime hours, then one needs to use the formula with $\mathrm{RF}_{1}$ and $\mathrm{RF}_{2}$ to calculate repair and maintenance costs.

\subsection{FUEL AND LUBRICATION}

ASABE (2006b) recommends using the actual power used to pull implements to calculate tractor fuel use. For a specific make and model of a tractor, it is recommended that one use data from the Nebraska Tractor Test Laboratory (Nebraska Tractor Test Laboratory 2008). In the absence of specific data, the ASAE has two methods for computing diesel fuel consumption (Note: most fuel use in agriculture is diesel.)

Average annual diesel consumption can be estimated in Section 6.2.1 of ASABE EP496.3 (ASABE 2006b) by:

$$
F=0.73 * 0.305 * P_{p t o}=0.22265 * P_{p t o}
$$

Where $\mathrm{F}=$ average fuel use, liters $(\mathrm{L})$ of diesel $/ \mathrm{h}$

$$
\mathrm{P}_{\text {pto }}=\text { maximum } \mathrm{PTO} \text { power, } \mathrm{kW}
$$

For English units, equation 2-8 becomes:

$$
F=0.73 * 0.6 * P_{p t o}=0.438 * P_{p t o}
$$

Where $\mathrm{F}=$ average fuel use, gallons of diesel $/ \mathrm{h}$

$\mathrm{P}_{\text {pto }}=$ maximum PTO power, $\mathrm{hp}$

The factor 0.73 in equations $2-8$ and 2-9 is the ratio of diesel to gasoline consumption. If gasoline is the fuel then the 0.73 should not be included in these equations.

Another set of equations is given in ASABE D497.5 (ASABE 2006a) to calculate the diesel consumption of tractors and combines. Additional equations (not shown) are also provided for gasoline and LPG fuel.

$$
\begin{array}{ll}
\text { SI } & F=2.64 X+3.91-0.203(738 X+173)^{0.5} \\
\text { English } & F=0.52 X+0.77-0.04(738 X+173)^{0.5}
\end{array}
$$

Where $\mathrm{F}_{\text {pto }}=$ typical fuel use for a specific operation, $\mathrm{L} /\left(\mathrm{kW}{ }^{-} \mathrm{h}\right)$ or gal $/(\mathrm{hp}-\mathrm{h})$

$\mathrm{X}=$ fraction of the maximum PTO used for a particular operation, fraction 
If one assumes that $X$ averages 0.5 , then the two methods, equations 2-8, 2-9, and 2-10, give similar answers. If the goal is to determine the average fuel consumption over a range of loads and over a period of time, equations 2-8 and 2-9 are recommended. Note that for both sets of equations from the ASABE Standards, fuel consumption is $15 \%$ higher than typical Nebraska Tractor Test performance to account for loss of efficiency in field conditions.

ASABE also provides equations for estimating the amount of lubricating oil needed (ASABE 2006a). However, calculating lubricating oil consumption is not necessary. ASABE estimates that lubrication costs, including the oil and filter, is $15 \%$ of fuel costs (ASABE 2006b).

In 2001, 2002, 2003, 2004, 2005, 2006, 2007, and 2008 the national average farm price of diesel was $\$ 0.285, \$ 0.255, \$ 0.328, \$ 0.346, \$ 0.520, \$ 0.601, \$ 0.642$, \$0.956/L (\$1.08, \$0.964, \$1.24, \$1.31, \$1.97, $\$ 2.28, \$ 2.43$, and $\$ 3.62 / \mathrm{gal}$ ), respectively (USDA/NASS 2004, 2008a,b). This price is for on farm use. For on road use, Federal and State taxes must be added. The Federal tax is $\$ 0.0645 / \mathrm{L}$ ( $\$ 0.244 / \mathrm{gal})$ and the average State tax is $\$ 0.0583 / \mathrm{L}$ ( $\$ 0.2205 / \mathrm{gal}$ ) (DOE/EIA 2008). In addition, some States levy sales tax and some local taxes also apply. For a complete listing by State and additional State and local taxes see Table EN1 in DOE/EIA (2008). The on road diesel price for 2007 is $\$ 0.765 / \mathrm{L}$ ( $\$ 2.89 / \mathrm{gal})$.

Table 2.5. On farm diesel prices 2001-2007

\begin{tabular}{|c|c|c|}
\hline Year & \$/L & \$/gal \\
\hline 2001 & 0.285 & 1.08 \\
\hline 2002 & 0.255 & 0.964 \\
\hline 2003 & 0.328 & 1.24 \\
\hline 2004 & 0.346 & 1.31 \\
\hline 2005 & 0.520 & 1.97 \\
\hline 2006 & 0.601 & 2.28 \\
\hline 2007 & 0.642 & 2.43 \\
\hline 2008 & 0.956 & 3.62 \\
\hline \multicolumn{3}{|c|}{ Source: USDA/NASS $(2004,2008 \mathrm{a}, \mathrm{b})$} \\
\hline
\end{tabular}

\subsection{INSURANCE, HOUSING, AND TAXES}

Insurance, housing, and taxes refer to fixed costs incurred by equipment ownership. Housing is the cost of shelter for equipment and taxes are paid on buildings. The AAEA (2000) refers to this as taxes, insurance, and shelter (TIS). If actual data are not available, ASABE suggests using the following: taxes $1.00 \%$, housing $0.75 \%$, and insurance $0.25 \%$, for a total of $2 \%$ of the purchase price (PP) as the annual cost of insurance, housing, and taxes. In their examples, the AAEA uses $2 \%$ of the average of purchase price plus salvage value (SV). Note that these two numbers will be different. For a machine with no salvage value the ASABE methodology gives annual costs twice as high the AAEA methodology. One would expect that insurance (presumably this is property insurance) and taxes (presumably this is property tax) would go down as equipment is depreciated. However, one would not expect housing costs to decrease as a machine ages. The appropriate methodology is probably somewhere in between these two methodologies. The authors suggest following the AAEA methodology of using $2 \%$ of the average of purchase price plus salvage value to estimate tax, insurance, and housing.

\subsection{LABOR}

Farm labor rates can be obtained from Farm Labor, a publication by the National Agricultural Statistics Service of the U.S. Department of Agriculture which is published quarterly (USDA/NASS 2008c). They list a number of farm labor rates: field, livestock, field and livestock, and all hired workers for 18 regions of the United States. We suggest using the wage rate for all hired workers. In the 
November issue average wage rates for hired workers for a calendar year are listed. Data for 2003 to 2008 for farm wage rates for all hired workers are shown in the Table 2.5.

In their examples the AAEA (2000) includes no benefits for farm workers except in their example of a California cotton-almond farm in the San Joaquin Valley. For the farm in the San Joaquin Valley they use a $34 \%$ benefits rate. The authors recommend using a fringe benefits rate of 30\%. Based on the 2007 data for the United States and, as a point of comparison, the four region of the Midwest (Lake, Cornbelt I, Cornbelt II, and Northern Plains), the average wage rate were $\$ 10.21$ and $\$ 10.72 / \mathrm{h}$, respectively, and with fringe benefits the labor rates were $\$ 13.27$ and $\$ 13.94 / \mathrm{h}$, respectively. We note that the wage rate in the Midwest is slightly higher than the average for the entire United States.

It is a common assumption in crop budgeting that more labor time is required than machine time in the field. The AAEA assumes that 1.2 labor hours are required for each machine hour. This is the assumption recommended by the authors of this report also. Applying this assumption to the average labor rate for the United States $(\$ 13.27 / \mathrm{h})$ results in a cost of $\$ 15.92 /$ machine $\mathrm{h}$.

Table 2.6. Wage rates for all hired workers in the United States $(\$ / \mathbf{h})$

\begin{tabular}{|c|c|c|c|c|c|c|}
\hline Region & 2008 & 2007 & 2006 & 2005 & 2004 & 2003 \\
\hline Northeast I & 10.96 & 10.49 & 10.35 & 9.88 & 9.96 & 9.93 \\
\hline Northeast II & 10.32 & 10.62 & 10.09 & 9.80 & 9.18 & 9.41 \\
\hline Appalachian I & 9.94 & 9.36 & 9.64 & 9.11 & 8.85 & 8.68 \\
\hline Appalachian II & 10.30 & 9.75 & 9.30 & 8.81 & 8.63 & 8.00 \\
\hline Southeast & 9.27 & 9.15 & 9.05 & 8.84 & 8.53 & 8.41 \\
\hline $\mathrm{FL}$ & 10.06 & 9.73 & 9.38 & 9.46 & 9.04 & 9.14 \\
\hline Lake & 11.25 & 10.87 & 10.37 & 10.08 & 9.88 & 9.80 \\
\hline Cornbelt I & 11.10 & 10.55 & 10.59 & 9.79 & 9.89 & 9.61 \\
\hline Cornbelt II & 11.24 & 11.10 & 10.65 & 10.16 & 9.45 & 9.75 \\
\hline Delta & 9.38 & 8.78 & 8.34 & 7.93 & 8.08 & 7.77 \\
\hline Northern Plains & 10.87 & 10.36 & 9.95 & 9.61 & 9.33 & 9.21 \\
\hline Southern Plains & 9.86 & 9.53 & 9.33 & 9.08 & 8.60 & 8.30 \\
\hline Mountain I & 9.99 & 9.24 & 9.25 & 8.84 & 8.55 & 7.98 \\
\hline Mountain II & 10.43 & 10.03 & 9.36 & 9.06 & 9.63 & 9.11 \\
\hline Mountain III & 10.46 & 9.37 & 8.91 & 8.61 & 8.18 & 8.08 \\
\hline Pacific & 10.69 & 10.69 & 10.37 & 9.62 & 9.61 & 9.25 \\
\hline CA & 11.04 & 10.54 & 10.09 & 9.76 & 9.33 & 9.25 \\
\hline $\mathrm{HI}$ & 13.22 & 12.84 & 12.18 & 11.58 & 11.34 & 11.33 \\
\hline US & 10.59 & 10.23 & 9.87 & 9.50 & 9.23 & 9.08 \\
\hline
\end{tabular}

\subsection{OVERHEAD}

Overhead is not always included in cost calculations. It is a fixed cost, applicable to the entire enterprise, and not specifically to machinery. Overhead includes such items as: office expense; fuel, lube, and utilities (not previously included in the machinery cost estimates); maintenance and repairs on buildings; machinery and equipment (not previously included in the machinery cost estimates); and farm insurance (not previously included in the machinery cost estimates) [Schedule 14.8 in AAEA (2000)]. The AAEA provides overhead estimates for various crops. In 1992 dollars (and converted to 2007 dollars 
using prices paid by farmers for production items, in $1992=101$ and in $2007=160$ ) the AAEA used the 1992 values shown in Table 2.6 in their examples:

Table 2.7. Overhead rates recommended by the AAEA for corn, soybeans, and alfalfa

\begin{tabular}{|l|c|c|c|c|}
\hline & \multicolumn{2}{|c|}{ 1992 dollars } & \multicolumn{2}{c|}{ 2007 dollars } \\
\hline Crop & \$/ha & \$/ac & \$/ha & \$/ac \\
\hline Corn & 24.03 & 9.73 & 38.07 & 15.41 \\
\hline Soybeans & 26.38 & 10.68 & 41.79 & 16.92 \\
\hline Alfalfa & 11.21 & 4.54 & 17.76 & 7.19 \\
\hline Source: (AAEA 2000)
\end{tabular}

In their examples the AAEA does not explain how they come up with how much overhead to allocate to each farm activity (crop and animal). The authors of this report suggest that an overhead charge of \$33/ha (\$13/acre) in 2007 dollars (the average overhead for corn, soybeans, and alfalfa), where appropriate, such as growing of switchgrass, but not for corn stover as it is a by-product of the corn grain production process.

\subsection{INTEREST}

The AAEA charges interest on operating expenses (e.g. fertilizers, fuel) and states that there is general agreement that interest should be charged on farm operations. However, there is no single agreed upon method of calculating interest charges, and the AAEA lists three alternatives. The second alternative described by AAEA (2000) is recommended here. This method assumes that operating inputs are charged interest for six months based on the discount rate (the interest rate used in calculating the present value of future cash flows). For baled corn stover the operating inputs are fuel and lubrication, repairs, and twine for baling. Baling incurs about a $\$ 0.30$ to $\$ 0.40 /$ dry $\mathrm{Mg}(\$ 0.27$ to $\$ 0.36 /$ dry ton) interest on operating expense charge, or less than $1 \%$ of the delivered cost (including grinding) to the conversion facility. For growing a crop such as corn or switchgrass, in addition to interest on machinery variable costs, interest on variable costs such as fertilizers and pesticides should be included in a complete crop budget.

\subsection{OPERATION OF POWERED EQUIPMENT}

Field efficiency is the ratio of productivity of a machine under field conditions to the theoretical machine productivity. It is estimated by a typical field efficiency reported by ASABE for each equipment type (ASABE 2006a). Hunt (1995) outlines ten factors that affect field efficiency:

1) Machine preparation time at the farmstead (could be any place away from the field)

2) Travel time to and from field

3) Machine preparation time in the field both before and after field operations

4) Theoretical field time (i.e. time spent in optimally performing intended field operation)

5) Turning time and time to cross nonproductive areas (e.g. grassed waterways)

6) Loading and unloading time

7) Machine adjustment time

8) Maintenance time in field

9) Repair time

10) Operator's personal time.

Field efficiency is defined by Hunt (1995) as item 4, theoretical field time, divided by the sum of items 4 to 9. Items $1,2,3$, and 10 are excluded in calculating field efficiency in the ASABE standards. However, equipment is often running to complete items $1,2,3$, and 10 above the time required for field operations. If this is true, it should be accounted for in cost estimations. 
The AAEA assumes that powered equipment operates $10 \%$ longer than the time required for field operations(AAEA 2000). Powered equipment includes tractors, self-propelled windrowers, self-propelled forage harvesters, and combines. This is not an assumption used by ASABE. This assumption means that if 0.20 hours are required to complete a field operation such as raking an acre, then the tractor had to run 0.22 hours, but the rake was only operated 0.20 hours. It seems reasonable to assume that power equipment operates some additional time above that required by the unpowered equipment. Note that labor is already assumed to be $20 \%$ greater than the time an implement operates, so only the nonlabor portion of the powered equipment cost is increased by $10 \%$

There are a number of ways to incorporate the extra $10 \%$ of time for power equipment into the budgeting process. Consider an example using a $90 \mathrm{~kW}(120 \mathrm{hp})$ tractor with a round baler with megatooth pickup and crop processor harvesting corn stover. Mesh wrap costs $\$ 2.76 /$ dry ton. The equipment cost in $\$ / \mathrm{h}$ is:

$\begin{array}{lr}\text { tractor } & 48.37 \\ \text { tractor }(10 \% \text { additional time, excluding labor) } & 51.62 \\ \text { round baler } & 35.87 \\ \text { megatooth pickup } & 1.07 \\ \text { crop processor } & 17.49\end{array}$

The cost of the tractor with $10 \%$ additional time (and labor cost of $\$ 15.92 / \mathrm{h})$ is calculated as: $(\$ 48.37 / \mathrm{h}$ $\$ 15.92 / \mathrm{h})^{*} 1.1+\$ 15.92 / \mathrm{h}=\$ 51.62 / \mathrm{h}$.

The total baler cost is $\$ 54.43 / \mathrm{h}$ (round baler, megatooth pickup, and crop processor). Assume that 9.07 dry $\mathrm{Mg}$ (10 dry tons) of stover per hour is baled. If $10 \%$ of additional time is added to the tractor operation, the cost is $\$ 15.00 / \mathrm{dry} \mathrm{Mg}(\$ 13.60 /$ dry ton). If no time is added to the tractor operating time for non-field work, the cost is $\$ 14.64 /$ dry $\mathrm{Mg}$ ( $\$ 13.28 /$ dry ton). So baling cost increases by $2.4 \%$ with the assumption that the tractor runs an additional $10 \%$ time above that required for the field operation.

When costing operations such as transporting bales or loose stover from the field to a storage facility, we assume a field efficiency of $80 \%$. This means that one calculates the amount of time it takes to load bales on the truck, drive over the road, weigh at a scale, unload, and travel back to the field and then assume that it actually takes $25 \%$ (1/0.8-1) longer to complete the operation. For out-of-the-field operations this adequately captures the additional $10 \%$ time that AAEA suggests a power machine operates in the field. It is recommended that the AAEA assumption that powered equipment operates $10 \%$ longer than is required to complete a field operation be incorporated in crop budgeting, but only for operations in the field (e.g. baling, mowing, raking).

\subsection{TRUCKING COSTS}

Data was obtained from Scott Paper during the early 1990s for an engineering-economic approach to costing trucking. Updated data is needed to for accurate, current trucking cost estimations. Until such data is available, cost estimations can be inflated to current dollars. We use a list price of approximately $\$ 95,000$ and $\$ 30,000$ for the truck tractor and flatbed trailer, respectively, and lifetime hours of 50,000 and annual use of 5,000 hours, respectively. If one calculates these costs, inflates them to 2007 dollars, and uses the 2007 diesel price, one gets $\$ 31.43 / \mathrm{h}$ including labor, and variable mileage costs (fuel, tires, maintenance, insurance) are $\$ 0.60 / \mathrm{km}(\$ 0.97 / \mathrm{mi})$ for a truck. The per $\mathrm{km}$ cost is based on diesel at its on road 2007 diesel price for 2007 of $\$ 0.765 / \mathrm{L}$ ( $\$ 2.89 / \mathrm{gal})$. If annual use is only $1,500 \mathrm{~h}$ and life is 15,000 hours (assume life stays the same at 10 years), then cost is $\$ 45 / \mathrm{h}$ plus variable mileage cost. The cost of a single flatbed trailer is $\$ 3.73 / \mathrm{h}$ if used 1500 hours per year or $\$ 1.98 / \mathrm{h}$ if used $5000 \mathrm{~h} / \mathrm{yr}$, plus $\$ 0.063 / \mathrm{km}$ $(\$ 0.102 / \mathrm{mi})$. For 5,000 hours of annual use, if a truck covers $50 \mathrm{~km}(30 \mathrm{mi})$ in a typical hour, then the cost of the truck $(\$ 61 / \mathrm{h})$ and single flatbed trailer $(\$ 4 / \mathrm{h})$ is about $\$ 65 / \mathrm{h}$. If the truck and trailer are used $1500 \mathrm{~h} / \mathrm{yr}$ [also covering $50 \mathrm{~km}(30 \mathrm{mi})$ in an hour], then the cost of a truck $(\$ 74 / \mathrm{h})$ and trailer $(\$ 6 / \mathrm{h})$ is about $\$ 80 / \mathrm{h}$. In the absence of specific data, it is recommended that one use an assumed cost of $\$ 65$ to $\$ 80 / \mathrm{h}$ for a truck with a single flatbed trailer. 


\section{FERTILIZER}

One of the major nonmachinery costs of growing a crop is fertilizer. The primary fertilizers are nitrogen, phosphorous, and potassium. In addition, limestone may be applied to increase $\mathrm{pH}$. Nitrogen comes in many forms [e.g. anhydrous ammonia, ammonium nitrate, nitrogen solutions $(28 \%, 30 \%$, and $32 \%$ ), urea, in mixtures with other fertilizers, and other forms with only nitrogen]. Phosphorus is usually applied as either monoammonium phosphate (MAP) or diammonium phosphate (DAP). Potassium is applied as potash and sometimes in mixtures with other fertilizers. Fertilizers are typically listed as \%N$\% \mathrm{P}_{2} \mathrm{O}_{5}-\% \mathrm{~K}_{2} \mathrm{O}$.

Average fertilizer prices are shown in Table 3.1, including calculated prices for nitrogen (as $\mathrm{N}$ ), phosphorous $\left(\right.$ as $\left.\mathrm{P}_{2} \mathrm{O}_{5}\right)$ and potassium as $\left(\mathrm{K}_{2} \mathrm{O}\right)$. Note that the price of nitrogen as anhydrous ammonia is considerably less than other forms of nitrogen, however it is more costly to apply. But even with application cost of about $\$ 0.11 / \mathrm{kg} \mathrm{N}(\$ 0.05 / \mathrm{lb} \mathrm{N})$ it is the least expensive form of inorganic nitrogen. Because phosphorus is typically sold in a mixture with nitrogen, pricing the phosphorous requires an assumption about the price of nitrogen. We have 3 different assumptions about the price of nitrogen: 1) nitrogen has a value of 0 (if applied to soybeans which require no nitrogen) [although this is debatable (see Brechbill and Tyner (2008), p. 14)], 2) nitrogen is valued at the price in anhydrous ammonia (e.g. for corn on which nitrogen is often applied as anhydrous ammonia), and 3) nitrogen is valued at a price representative of nitrogen solutions and urea.

Table 3.1. 2007 fertilizer prices

\begin{tabular}{|c|c|c|c|c|c|c|c|}
\hline \multirow{2}{*}{ Nitrogen } & $\mathbf{N}$ & $\mathbf{P}_{2} \mathbf{O}_{5}$ & $\mathrm{~K}_{2} \mathrm{O}$ & Price & $\mathbf{N}$ & $\mathbf{P}_{2} \mathbf{O}_{5}$ & $\mathrm{~K}_{2} \mathrm{O}$ \\
\hline & \multicolumn{3}{|c|}{ Fraction } & $\$ /$ ton & \multicolumn{3}{|c|}{$\$ / \mathbf{l b}$} \\
\hline Anhydrous ammonia & 0.82 & 0 & 0 & 523 & 0.319 & & \\
\hline Ammonium nitrate & 0.335 & 0 & 0 & 382 & 0.570 & & \\
\hline Solution & 0.28 & 0 & 0 & 276 & 0.493 & & \\
\hline Solution & 0.32 & 0 & 0 & 308 & 0.481 & & \\
\hline Urea & 0.45 & 0 & 0 & 453 & 0.503 & & \\
\hline \multicolumn{8}{|l|}{ Phosphorous } \\
\hline Triple superphosphate & 0 & 0.45 & 0 & 418 & & 0.464 & \\
\hline \multicolumn{8}{|l|}{ Potassium } \\
\hline Muriate of potash & 0 & 0 & 0.61 & 280 & & & 0.230 \\
\hline \multicolumn{8}{|l|}{ Mixed fertilizer } \\
\hline Monoammonium phosphate & \multirow{3}{*}{0.11} & \multirow{3}{*}{0.52} & \multirow{3}{*}{0} & \multirow{3}{*}{445} & 0 & 0.428 & \\
\hline $\begin{array}{l}\mathrm{N} \text { valued at anhydrous ammonia plus } \$ 0.11 / \mathrm{kg} \\
(\$ 0.05 / \mathrm{lb}) \text { application cost }\end{array}$ & & & & & 0.369 & 0.350 & \\
\hline $\begin{array}{l}\mathrm{N} \text { valued at typical value for other than } \\
\text { anhydrous ammonia }\end{array}$ & & & & & 0.500 & 0.322 & \\
\hline Diammonium phosphate & \multirow{3}{*}{0.18} & \multirow{3}{*}{0.46} & \multirow{3}{*}{0} & \multirow{3}{*}{431} & 0 & 0.480 & \\
\hline $\begin{array}{l}\mathrm{N} \text { valued at anhydrous ammonia plus } \$ 0.11 / \mathrm{kg} \\
(\$ 0.05 / \mathrm{lb}) \text { application cost }\end{array}$ & & & & & 0.369 & 0.336 & \\
\hline $\begin{array}{l}\mathrm{N} \text { valued at typical value for other than } \\
\text { anhydrous ammonia }\end{array}$ & & & & & 0.500 & 0.285 & \\
\hline
\end{tabular}

\section{MACHINERY PERFORMANCE IN HANDLING AND PROCESSING BIOMASS}

To estimate costs of handling and processing biomass, the hourly costs, as described in Section 2, are needed along with the time required to complete an operation. Therefore, an estimate of the time required 
for an operation to cover a certain area of the field or process a certain tonnage of material is needed. Once this time is known, then it can be multiplied by the cost of the machine determined in section 2 to calculate $\$ / \mathrm{Mg}$, or $\$ / \mathrm{ha}$, or $\$ /$ bale (knowing the weight of each bale).

\subsection{PERFORMANCE OF FIELD EQUIPMENT}

Equipment field performance is calculated from the width of cut and ground speed.

$$
\mathrm{t}=\mathrm{C}_{1} \frac{\mathrm{A}}{(\mathrm{s})(\mathrm{w})(\mathrm{e})}+\mathrm{t}_{\mathrm{m}}
$$

where $\mathrm{t}=$ time required for operation to be completed, $\mathrm{h}$

$\mathrm{C}_{1}=$ coefficient for equation consistency $\left(\mathrm{C}_{1}=10\right.$ when ha, $\mathrm{km} / \mathrm{h}$, and $\mathrm{m}$ are used $)$

$\mathrm{A}=$ covered area, ha

$\mathrm{s}=$ equipment speed, $\mathrm{km} / \mathrm{h}$

$\mathrm{w}=$ cut width, $\mathrm{m}$

$\mathrm{e}=$ efficiency of equipment, decimal

$\mathrm{t}_{\mathrm{m}}=$ time in field for operations other than travel (e.g. time to tie or to wrap bale)

If units on $\mathrm{A}, \mathrm{s}$, and $\mathrm{w}$ are $\mathrm{ac}, \mathrm{mi} / \mathrm{h}$, and $\mathrm{ft}$, respectively, then $\mathrm{C}_{1}=8.25$.

ASABE (2006a) publishes an estimate of performance data for agricultural equipment. Table 4.1 is extracted from the published data in the ASAE standard for equipment whose performance depends on the speed. Table 4.1 also lists ranges of efficiencies and typical efficiency. Efficiencies are calculated as the time during which useful work is done divided by the total time spent in the field.

Table 4.1. Field efficiencies and speeds of agricultural equipment

\begin{tabular}{|l|c|c|c|c|c|c|}
\hline \multirow{2}{*}{\multicolumn{1}{|c|}{ Machine }} & \multicolumn{2}{|c|}{ Field efficiency } & \multicolumn{4}{c|}{ Field speed } \\
\cline { 2 - 7 } & $\begin{array}{c}\text { Range } \\
\mathbf{( \% )}\end{array}$ & $\begin{array}{c}\text { Typical } \\
\mathbf{( \% )}\end{array}$ & $\begin{array}{c}\text { Range } \\
\mathbf{( m i / h )}\end{array}$ & $\begin{array}{c}\text { Typical } \\
\mathbf{( m i / h )}\end{array}$ & $\begin{array}{c}\text { Range } \\
\mathbf{( k m / h )}\end{array}$ & $\begin{array}{c}\text { Typical } \\
\text { (mi/h) }\end{array}$ \\
\hline Combine (self-propelled) & $65-80$ & 70 & $2.0-5.0$ & 3.0 & $3.0-6.5$ & 5.0 \\
\hline Mower & $75-85$ & 80 & $3.0-6.0$ & 5.0 & $5.0-10.0$ & 8.0 \\
\hline Mower (rotary) & $75-90$ & 80 & $5.0-12.0$ & 7.0 & $8.0-19.0$ & 11.0 \\
\hline Mower-conditioner & $75-85$ & 80 & $3.0-6.0$ & 5.0 & $5.0-10.0$ & 8.0 \\
\hline Mower-conditioner (rotary) & $75-90$ & 80 & $5.0-12.0$ & 7.0 & $8.0-19.0$ & 11.0 \\
\hline Windrower (self-propelled) & $70-85$ & 80 & $3.0-8.0$ & 5.0 & $5.0-13.0$ & 8.0 \\
\hline Rake (side-delivery) & $70-90$ & 80 & $4.0-8.0$ & 6.0 & $6.5-13.0$ & 10.0 \\
\hline Baler (large rectangular) & $70-90$ & 80 & $4.0-8.0$ & 5.0 & $6.5-13.0$ & 8.0 \\
\hline Baler (large round) & $55-75$ & 65 & $3.0-8.0$ & 5.0 & $5.0-13.0$ & 8.0 \\
\hline Forage harvester & $60-85$ & 70 & $1.5-5.0$ & 3.0 & $2.5-8.0$ & 5.0 \\
\hline Forage harvester (self- propelled) & $60-85$ & 70 & $1.5-6.0$ & 3.5 & $2.5-10.0$ & 5.5 \\
\hline Fertilizer spreader & $60-80$ & 70 & $5.0-10.0$ & 7.0 & $8.0-16.0$ & 11.0 \\
\hline Boom-type sprayer & $50-80$ & 65 & $3.0-7.0$ & 6.5 & $5.0-11.5$ & 10.5 \\
\hline Source: ASABE (2006b) & & & & & & \\
\hline
\end{tabular}

Speed, which significantly affects field performance, varies widely as shown in Table 4.1. Crop yield (crop density) affects the speed of field equipment. Operators vary field speed in order to make the equipment to run at design capacity. For example a baler field speed can be estimated from: 


$$
\mathrm{s}=\mathrm{C}_{2} \frac{\mathrm{Q}}{\mathrm{wY}}
$$

Where $\mathrm{Q}=$ amount biomass processed per hour, $\mathrm{Mg} / \mathrm{h}$

$\mathrm{C}_{2}=$ coefficient for unit consistency

$\mathrm{Y}=$ yield, $\mathrm{Mg} / \mathrm{ha}$

$\mathrm{w}=$ width of cut (or effective width with a rake or windrower), $\mathrm{m}$

Width of cut (or effective width with a rake or windrower) is chosen such that adequate material is in the swath so a baler can operate at a reasonable speed and perform at its rated capacity.

For equipment, service time ( $\mathrm{t}$ ) (i.e. the amount of time required for the operation) is calculated by:

$$
\mathrm{t}=\frac{\mathrm{AY}}{\mathrm{qe}}
$$

where $\mathrm{A}=$ area covered, ha

$\mathrm{Y}=$ net yield, dry $\mathrm{Mg} / \mathrm{ha}$

$\mathrm{q}=$ unit throughput, dry $\mathrm{Mg} / \mathrm{h}$

$\mathrm{e}=$ efficiency of equipment, decimal

\subsection{TRANSPORT EQUIPMENT PERFORMANCE}

Estimations of transport time include travel time, loading time, and unloading time as shown in equation 4-4.

$$
t_{t r}=\frac{t_{\text {haul }}+t_{\text {return }}+t_{l d}+t_{u l d}}{e}
$$

where $t_{t r}=$ total transport time per load, $h$

$t_{\text {haul }}, t_{\text {return }}$ are the forward and return time of the transporter per load, respectively, $h$

$t_{l d}, t_{\text {uld }}=$ loading and unloading times per load, respectively, $h$

$\mathrm{e}=$ constant $(\leq 1)$ to account for turns and obstacles that increase transport time

Transporter capacity, $\mathrm{W}_{\mathrm{b}}$, is expressed in terms of mass to be transported (equation 4-5).

$$
\mathrm{W}_{\mathrm{b}}=\mathrm{k} \rho_{\mathrm{b}} \mathrm{V}
$$

where $\mathrm{W}_{\mathrm{b}}=$ transporter capacity, wet $\mathrm{Mg}$

$\mathrm{k}=$ coefficient $(\leq 1)$ to account for incomplete loading of the truck

$\rho_{\mathrm{b}}=$ bulk density of the biomass, $\mathrm{kg} / \mathrm{m}^{3}$

$\mathrm{V}=$ volume of the container, $\mathrm{m}^{3}$.

The coefficient $\mathrm{k}$ represents less than full situations (Sokhansanj et al. 2006). It is found by considering the deviation of the top of the biomass pile in a truck to the straight plane along the top of the truck container. It should be noted that $\mathrm{W}_{\mathrm{b}}$ has a maximum value based on legal weight limits. In other words, if the transporter capacity would exceed legal limits, then the biomass volume must be reduced (in equation 4-5, this would require adjustment of the $\mathrm{V}$ or $\mathrm{k}$ terms). 
In the absence of data on bulk density of biomass at given moisture content, it is assumed that volume remains unchanged when moisture content of biomass changes. The wet bulk density can be estimated from equation 4-6 below.

$$
\rho_{b}=\rho_{d}\left(1+M_{w}\right)
$$

where $\rho_{b}=$ moist bulk density, $\mathrm{kg} / \mathrm{m}^{3}$

$\rho_{\mathrm{d}}=$ dry bulk density, $\mathrm{kg} / \mathrm{m}^{3}$

$\mathrm{M}_{\mathrm{w}}=$ wet basis moisture content, decimal.

Once the capacity of the truck, $\mathrm{W}_{\mathrm{b}}$, and the total transport rate are known, the effective transport rate, $\mathrm{W}_{\mathrm{t}}$, can be determined by equation 4-7.

$$
\mathrm{W}_{\mathrm{t}}=\frac{\mathrm{W}_{\mathrm{b}}}{\mathrm{t}_{\mathrm{tr}}}
$$

where $\mathrm{W}_{\mathrm{t}}=$ rate of biomass transportation, $\mathrm{Mg} / \mathrm{h}$

\section{STORAGE COSTING METHODOLOGY}

To accommodate year-round bioenergy production with a seasonal feedstock, biomass must often be stored from the time it is harvested until it is needed by the biorefinery or power plant. The goal of a storage system is to minimize dry matter loss and protect, and enhance when possible, the quality of biomass until it is utilized. This section briefly highlights some factors to consider in performing an economic analysis of a biomass storage system. The information discussed here focuses on baled biomass. Currently, biomass is typically stored dry as bales (maximum moisture content for dry harvest varies with crop, but it is usually no more than $20 \%$ moisture content, wet basis). In some regions conditions are not favorable during the harvest season for timely drying of biomass. In these locations, wet storage techniques should be considered. There is limited research literature regarding the economics of wet storage. Shinners et al. (2007) evaluated the costs of ensiling corn stover and Turhollow and Sokhansanj (2007) performed an extensive economic analysis of storing high moisture corn stover in large piles similar to a bagasse storage method used by the pulping industry.

\subsection{ESTIMATING STORAGE AREA REQUIRED}

The storage location should be designed (1) to accommodate the biomass footprint, (2) allow space for maneuvering large equipment, and (3) minimize fire hazard to surrounding buildings (the International Fire Code (IFC) (2006), or other applicable fire code, should be consulted). The biomass footprint will vary with storage location (on-farm satellite storage vs. refinery short-term storage), format (round bales vs. rectangular bales vs. loose), and bulk density. For indoor biomass storage, stack height should allow ample clearance between the top of bales and the ceiling for removing and placing bales.

\subsection{CAPITAL RECOVERY OF FACILITIES}

As discussed in Section 2, capital recovery is the annual cost of money for purchase of an asset (e.g. piece of equipment, building, or site preparation). It includes loss in value of the asset (depreciation) and interest. Including interest reflects the cost of borrowing money, or if money was not borrowed, the money that could have been earned if the money had been invested. The salvage value of structures is difficult to estimate; therefore a common practice is to assume a long useful life and little to no salvage 
value (AAEA 2000. As a conservative estimate, a zero salvage value is recommended here for structures. Likewise, the salvage value for hay tarps and gravel pads is zero). This simplifies the capital recovery equation (equation 2-3) to equation 5-1. Table 5.2 shows estimated investment costs, useful lives, and capital recovery factors of various components of biomass storage systems. In this case Cap is an annual cost, not an hourly cost as is used for equipment.

$$
\mathrm{Cap}=(\mathrm{PP})\left(\frac{\mathrm{i}}{1-(1+\mathrm{i})^{-\mathrm{n}}}\right)
$$

where Cap $=$ annual capital cost, $\$$

$\mathrm{PP}=$ purchase price, $\$$

$\mathrm{i}=$ interest rate, decimal

$\mathrm{n}=$ life of investment, years

\subsection{OTHER OWNERSHIP COSTS}

Other ownership costs that should be accounted for in evaluating biomass storage options are insurance, taxes, and repair. Insurance, taxes, and repair can each be estimated as a percentage of the purchase price. An extension factsheet by Gay and Grisso (2002) recommend using the following values for these costs: property taxes $1 \%$, insurance $0.3 \%$, and repairs $0.7 \%$.

\subsection{LAND}

To account for the costs associated with the use of farm land, AAEA (2000) recommends using cash rental value. Cash rental value best measures the land's opportunity costs, user costs, property taxes, and other overhead costs. The USDA National Agricultural Statistics Service (NASS) publishes an annual summery of farm land values that includes average cash rental value (USDA/NASS 2007). In 2007, the US average annual cash rent for cropland was $\$ 210 /$ ha (\$85/ac) with state averages ranging from $\$ 67 /$ ha (\$27/ac) in Oklahoma to $\$ 840 /$ ha $(\$ 340 /$ ac) for irrigated cropland in California. Rental values for pasture land were significantly lower. The US average annual rent for pasture was $\$ 30 /$ ha $(\$ 12 / \mathrm{ac})$.

\subsection{LABOR}

Cost estimates for buildings, gravel pads, and wrapping bales shown in Table 5.1 include the labor required to build/prepare the storage site or to wrap bales with plastic. When considering storage of baled biomass under tarps, the labor required to place and remove hay tarps should also be accounted for. Holmes (2004) estimates that 0.054 person- $\mathrm{h} / \mathrm{m}^{2}\left(0.005\right.$ person- $\left.\mathrm{h} / \mathrm{ft}^{2}\right)$ of tarp area is needed for placing and removing tarps. Assuming a labor rate of $\$ 10 / \mathrm{h}, \$ 0.54 / \mathrm{m}^{2}\left(\$ 0.05 / \mathrm{ft}^{2}\right)$ of tarp should be included in annual cost estimations. 
Table 5.1. Estimated investment costs and useful lives for components of biomass storage systems

\begin{tabular}{|c|c|c|}
\hline Stora & Costs & Useful life \\
\hline $\begin{array}{l}\text { Structures for } \\
\text { baled biomass }\end{array}$ & $\begin{array}{l}\text { Pole frame structure, all sides open: } \$ 71.37 / \mathrm{m}^{2}\left(\$ 6.63 / \mathrm{ft}^{2}\right)^{\mathrm{ab}} \\
\text { Pole frame structure, one side open: } \$ 99.35 / \mathrm{m}^{2}\left(\$ 9.23 / \mathrm{ft}^{2}\right)^{\mathrm{ab}} \\
\text { Pole frame structure, enclosed: } \$ 111.62 / \mathrm{m}^{2}\left(\$ 10.37 / \mathrm{ft}^{2}\right)^{\mathrm{ab}} \\
\text { Enclosed shed w/ concrete floor \& foundation: } \$ 169.43 / \mathrm{m}^{2}\left(\$ 15.74 / \mathrm{ft}^{2}\right)^{\mathrm{c}}\end{array}$ & 20 years $^{\mathrm{d}}$ \\
\hline Bunker silo & Concrete floor and walls, plastic covering: $\$ 150.59 / \mathrm{m}^{2}\left(\$ 13.99 / \mathrm{ft}^{2}\right)^{\text {efgh }}$ & 20 years \\
\hline Storage pad & $\begin{array}{l}\text { Gravel: } \$ 11.75 / \mathrm{m}^{2}\left(\$ 1.09 / \mathrm{ft}^{2}\right)^{\mathrm{ig}} \\
\text { Asphalt: } \$ 30.68 / \mathrm{m}^{2}\left(\$ 2.85 / \mathrm{ft}^{2}\right)^{\mathrm{gj}}\end{array}$ & 10 years $^{\mathrm{k}}$ \\
\hline Hay tarp & $\$ 2.91 / \mathrm{m}^{2}\left(\$ 0.27 / \mathrm{ft}^{2}\right)(\text { of tarp area })^{\operatorname{lm}}$ & 5 years $^{\mathrm{f}}$ \\
\hline Plastic wrap & $\$ 3.11 /$ bale or $\$ 6.71 / \mathrm{Mg}(\$ 6.09 / \text { dry ton })^{\mathrm{n}}$ & 1 year \\
\hline \multicolumn{3}{|c|}{$\begin{array}{l}{ }^{\mathrm{a}} \text { Costs of storage structures based on data for pole barns with } 5.5-\mathrm{m}(18-\mathrm{ft}) \text { walls from Ogershok (2008) } \\
\text { b Cost includes gravel floor. Concrete floor will add approximately } \$ 32 / \mathrm{m}^{2}\left(\$ 3 / \mathrm{ft}^{2}\right) \text { (estimated as in bunker } \\
\text { silo floor, note e below) to cost of structure }\end{array}$} \\
\hline \multicolumn{3}{|c|}{${ }^{\mathrm{c}}$ Cost estimated as average cost of average quality hay barn with concrete floor added $\left(\$ 32.29 / \mathrm{m}^{2}, \$ 3 / \mathrm{ft}^{2}\right)$} \\
\hline \multicolumn{3}{|c|}{${ }^{\mathrm{d}}$ Average physical life for barns (Ogershok 2008) } \\
\hline \multicolumn{3}{|c|}{$\begin{array}{l}\text { e Bunker silo floor cost estimated based on RSMeans }(2007) \text { as the sum of } 9 \text { inches of topsoil removal } \\
\left(\$ 0.32 / \mathrm{m}^{2}, \$ 0.03 / \mathrm{ft}^{2}\right), 9 \text {-inch deep gravel base }(3 / 4 \text { " crushed rock) as recommended by Miller and Marter } \\
\left.(2003) \text { for } 12-\mathrm{ft}_{\text {tall }} \text { wall } \$ 14.64 / \mathrm{m}^{2}, \$ 1.36 / \mathrm{ft}^{2}\right), 4 \text { inch thick concrete floor }\left(\$ 19.81 / \mathrm{m}^{2}, \$ 1.84 / \mathrm{ft}^{2}\right) \text {, and } \\
\text { concrete finishing }\left(\$ 1.51 / \mathrm{m}^{2}, \$ 0.14 / \mathrm{ft}^{2}\right)\end{array}$} \\
\hline \multicolumn{3}{|c|}{$\begin{array}{l}\text { f Bunker silo wall cost estimates ( } \$ \text { per linear foot) from Holmes (2004) and updated to } 2008 \text { dollars using } \\
\text { "Index of Prices Paid by Farmers" for building materials (USDA/NASS 2008a, 2009) }\end{array}$} \\
\hline \multicolumn{3}{|c|}{$\begin{array}{l}\text { g A location factor of } 0.839 \text { (average for Iowa) was included in calculations based on data from RSMeans } \\
\text { (2007) to adjust US average costs for rural, crop intensive regions }\end{array}$} \\
\hline \multicolumn{3}{|c|}{$\begin{array}{l}\text { h } \text { Bunker silo cost estimate includes plastic covering at } \$ 1.08 / \mathrm{m}^{2}\left(\$ 0.10 / \mathrm{ft}^{2}\right) \text {, based on average of costs } \\
\text { reported by three vendors of clear, } 6 \text {-mil polyethylene plastic (February 2008). Additional supplies, such } \\
\text { as old tires, are needed to hold plastic in place. It is assumed that these can be obtained at no charge }\end{array}$} \\
\hline \multicolumn{3}{|c|}{$\begin{array}{l}\text { i Cost of constructing gravel pad was based on data provided by RSMeans }(2007) \text { as the sum of } 9 \text { inches of } \\
\text { topsoil removal }\left(\$ 0.32 / \mathrm{m}^{2}, \$ 0.03 / \mathrm{ft}^{2}\right) \text {, geotextile fabric, and a } 6 \text { inch deep } 3 / 4 \text { " crushed stone base, } \\
\text { compacted }\left(\$ 10.01 / \mathrm{m}^{2}, \$ 0.93 / \mathrm{ft}^{2}\right)\end{array}$} \\
\hline \multicolumn{3}{|c|}{$\begin{array}{l}{ }^{j} \text { Asphalt pad cost estimate is sum of topsoil removal }\left(\$ 0.32 / \mathrm{m}^{2}, \$ 0.03 / \mathrm{ft}^{2}\right) \text { and asphaltic concrete } \\
\left(\$ 30.35 / \mathrm{m}^{2}, \$ 2.82 / \mathrm{ft}^{2}\right)\end{array}$} \\
\hline \multicolumn{3}{|c|}{${ }^{\mathrm{k}}$ Useful life for outdoor storage sites is based on Burdine et al. (2005) } \\
\hline \multicolumn{3}{|c|}{$\begin{array}{l}{ }^{1} \text { The cost of a hay tarp was estimated based on the average of costs reported by two vendors (Gempler's } \\
2008 \text {, Tarps Plus 2007) as }\left(\$ 2.37 / \mathrm{m}^{2}, \$ 0.22 / \mathrm{ft}^{2}\right)\end{array}$} \\
\hline \multicolumn{3}{|c|}{${ }^{\mathrm{m}}$ Includes cost of labor to place and remove tarp as described in Section 5.5} \\
\hline \multicolumn{3}{|c|}{$\begin{array}{l}{ }^{\mathrm{n}} \text { Estimated cost for } 1.22-\mathrm{m} \times 1.22-\mathrm{m} \times 2.44-\mathrm{m}(4-\mathrm{ft} \times 4-\mathrm{ft} \times 8-\mathrm{ft}) \text { bales stacked } 2 \text { high and wrapped with } 8 \\
\text { layers of plastic using a Stinger Cube Line Wrapper includes equipment, materials, and labor }\end{array}$} \\
\hline
\end{tabular}

\subsection{IMPACTS OF DRY MATTER LOSS ON COST ESTIMATES}

During biomass storage, dry matter can be lost due to weathering (primarily by precipitation and/or water absorption from the ground). The amount of dry matter lost varies significantly with storage method as shown in Table 5.1. Note that although Table 5.2 gives estimated dry matter loss for round bales of hay, storage losses in rectangular bales could vary significantly from these estimates depending on ambient weather conditions. Note also that the values in Table 5.2 are for hay and dry matter losses for other biomass crops such as corn stover and switchgrass may differ. One should consult research 
literature to find an appropriate estimation of dry matter loss for the crop being evaluated for a reliable economic evaluation. The estimations provided here are for purposes of illustration only.

Table 5.2. Estimated dry matter loss in round bales of hay for various storage methods.

\begin{tabular}{|l|c|}
\hline \multicolumn{1}{|c|}{ Storage method } & Estimated annual dry matter loss, $\%$ \\
\hline Enclosed shed & $2-5$ \\
\hline Open-sided pole structure & $3-10$ \\
\hline Reusable tarp on gravel pad & $5-10$ \\
\hline Plastic wrap on ground & $4-7$ \\
\hline Uncovered on gravel pad & $13-17$ \\
\hline \multicolumn{2}{|l|}{ Sources: Collins et al. (1997), Huhnke (2006), Shinners et al. (2007) } \\
\hline
\end{tabular}

The total cost of biomass storage is the sum of the storage site or materials cost and the cost of dry matter loss during storage. Equation 5-2 can be used to adjust the storage cost to include dry matter loss. This equation adjusts the estimated cost of the storage site and materials to account for probable loss of material during storage. To illustrate, consider a storage building that is known to cost $\$ 11.75$ per dry $\mathrm{Mg}$ (\$10.66/dry ton) of biomass. If 100 dry $\mathrm{Mg}$ (110 dry tons) of biomass is placed in storage the ideal (i.e. no losses) cost of storage is $\$ 1175$. But if $5 \%$ of the dry matter is lost and only $95 \%$ of the dry matter is retrieved one year later, the cost of storage based on the remaining material is $\$ 1175 / 95$ dry $\mathrm{Mg}=$ $\$ 12.37 /$ dry $\mathrm{Mg}(\$ 11.23 /$ dry ton $)$.

$$
\mathrm{C}_{\mathrm{s}}=\mathrm{C}_{\mathrm{o}}\left(\frac{1}{1-\mathrm{DML}}\right)
$$

$$
\begin{aligned}
& \text { Where } \mathrm{C}_{\mathrm{s}}=\text { annual cost to store biomass, } \$ / \mathrm{dry} \mathrm{Mg}(\$ / \mathrm{dry} \text { ton }) \\
& \mathrm{C}_{\mathrm{o}}=\text { ownership cost of storage site, } \$ / \mathrm{dry} \mathrm{Mg}(\$ / \text { dry ton }) \\
& \mathrm{C}_{\mathrm{o}}=\frac{\mathrm{Cap}}{\mathrm{W}_{\text {store }}} \\
& \mathrm{Cap}=\text { structure capital cost from equation } 5-1, \$ \\
& \mathrm{~W}_{\text {store }}=\text { mass of biomass in storage, dry Mg }(\text { dry ton }) \\
& \text { DML }=\text { dry matter loss, decimal }
\end{aligned}
$$

\section{EXAMPLES OF BIOMASS COSTING METHODOLOGY}

To illustrate how the costing methodology described in this report can be used to evaluate design of biomass supply chains, three examples are given. In the first example (section 6.1), tall fescue in an existing pasture is harvested as silage. The second example (section 6.2) focuses on storage of dry biomass bales.

\subsection{HARVESTING AN EXISTING PASTURE AS A SILAGE-TYPE CROP}

In the following example, an existing tall fescue pasture is fertilized annually with $112 \mathrm{~kg} / \mathrm{ha} \mathrm{(100}$ $\mathrm{lb} / \mathrm{ac}$ ) nitrogen (as N), $44.8 \mathrm{~kg} / \mathrm{ha}(40 \mathrm{lb} / \mathrm{ac})$ phosphate $\left(\mathrm{as}_{2} \mathrm{O}_{5}\right)$, and $44.8 \mathrm{~kg} / \mathrm{ha}(40 \mathrm{lb} / \mathrm{ac})$ potash (as $\mathrm{K}_{2} \mathrm{O}$ ). Every three years lime is applied at $2.24 \mathrm{Mg} / \mathrm{ha}(1.0$ ton/ac). These, plus interest on these costs, are the only variable costs outside of those of the harvest machinery. Harvest is done once annually using silage equipment. The producer harvests the biomass himself using an $89.5 \mathrm{~kW}(120 \mathrm{hp})$ tractor. On the first pass, the tractor pulls a mower-conditioner that cuts down the tall fescue and some field drying occurs to $40 \%$ moisture (on a wet basis). A few days later the tractor pulls a forage harvester with a windrow pickup head and a high dump forage wagon [capacity of $26.9 \mathrm{~m}^{3}\left(950 \mathrm{ft}^{3}\right)$ with a roof] behind. After the wagon is filled, the farmer moves the tractor plus forage harvester and wagon to the field edge 
where the wagon is dumped into a large trailer with a capacity of at least $135 \mathrm{~m}^{3}\left(4750 \mathrm{ft}^{3}\right)$. We assume that the forage harvester can process the tall fescue to a density of $73.6 \mathrm{dry} \mathrm{kg} / \mathrm{m}^{3}\left(4.6 \mathrm{dry} \mathrm{lb} / \mathrm{ft}^{3}\right)$, the high dump forage wagon carries a load of 1.98 dry $\mathrm{Mg}$ (2.185 dry tons), and the trailer can carry load of 9.91 dry $\mathrm{Mg}$ (10.925 dry tons) or $19.8 \mathrm{Mg}$ (21.85 tons) or 5 high dump forage wagon loads. Yield is assumed to be 9 dry $\mathrm{Mg} / \mathrm{ha}$ (4.02 dry tons/ac) in a single cutting. The tractor is used for approximately $800 \mathrm{~h} / \mathrm{yr}$; and the mower-conditioner, forage harvester, pickup head, and high dump forage wagon for $300 \mathrm{~h} / \mathrm{yr}$. Costs are calculated in year 2007 dollars. Costs that must be recovered include variable, harvest (machinery), and fixed costs. A summary of costs of production is presented in Table 6.1. The details of the calculations are presented following the summary table.

Table 6.1. Summary of production costs for silage harvest example

\begin{tabular}{|l|c|c|c|c|c|c|c|c|}
\hline & Unit & Quantity & $\begin{array}{c}\text { Unit } \\
\text { price }\end{array}$ & $\begin{array}{c}\text { Total } \\
\text { (\$/ac) }\end{array}$ & Unit & Quantity & $\begin{array}{c}\text { Unit } \\
\text { price }\end{array}$ & $\begin{array}{c}\text { Total } \\
\text { (\$/ha) }\end{array}$ \\
\hline Variable costs - fertilizer & & & & & & & & \\
\hline $\mathrm{N}$ & $\mathrm{lb}$ & 100 & 0.50 & 50.00 & $\mathrm{Kg}$ & 112 & 1.102 & 123.42 \\
\hline $\mathrm{P}_{2} \mathrm{O}_{5}$ & $\mathrm{lb}$ & 40 & 0.30 & 12.00 & $\mathrm{Kg}$ & 44.8 & 0.661 & 29.61 \\
\hline $\mathrm{K}_{2} \mathrm{O}$ & $\mathrm{lb}$ & 40 & 0.23 & 9.08 & $\mathrm{~kg}$ & 44.8 & 0.507 & 22.71 \\
\hline Lime (prorated) & ton & 0.333 & 23.00 & 7.66 & $\mathrm{Mg}$ & 0.746 & 25.35 & 18.91 \\
\hline $\begin{array}{l}\text { Total variable costs before } \\
\text { interest on variable costs }\end{array}$ & & & & 78.74 & & & & 194.65 \\
\hline Interest on variable costs & $\$$ & 78.74 & $3 \%$ & 2.36 & $\$$ & 194.65 & $3 \%$ & 5.84 \\
\hline Total variable costs & & & & 81.10 & & & & 200.49 \\
\hline Harvest costs & tons & 4.02 & 16.25 & 65.32 & $\mathrm{Mg}$ & 9 & 17.94 & 161.48 \\
\hline Fixed costs & & & & & & & & \\
\hline Overhead & acre & & & 13.00 & $\mathrm{ha}$ & & & 32.11 \\
\hline Land rent & acre & & & 25.00 & $\mathrm{ha}$ & & & 61.75 \\
\hline Total costs & & & & 184.42 & & & & 455.83 \\
\hline Yield & & & & $\begin{array}{c}4.017 \\
\text { dry tons/ac }\end{array}$ & & & & 9 \\
\hline Total costs & & & & $\begin{array}{c}\mathbf{4 5 . 9 1} \\
\text { \$/dry ton }\end{array}$ & & & & $\begin{array}{c}\mathbf{5 0 . 6 5} \\
\text { dry } \mathrm{Mg} / \mathrm{ha}\end{array}$ \\
\hline
\end{tabular}

\subsubsection{Variable costs}

Variable costs were fertilizers (nitrogen, phosphorus, and potassium), lime, and interest on these variable operating costs. Nitrogen (as N) was applied at a rate of $112 \mathrm{~kg} / \mathrm{ha}(100 \mathrm{lb} / \mathrm{ac})$ and costs $\$ 1.12 / \mathrm{kg}(\$ 0.50 / \mathrm{lb})$, for a total cost of $\$ 123 / \mathrm{ha}(\$ 50 / \mathrm{ac})$. Phosphorus $\left(\right.$ as $\left.\mathrm{P}_{2} \mathrm{O}_{5}\right)$ was applied at a rate of 45 $\mathrm{kg} / \mathrm{ha}(40 \mathrm{lb} / \mathrm{ac})$ and costs $\$ 0.66 / \mathrm{kg}(\$ 0.30 / \mathrm{lb})$, for a total cost of $\$ 30 / \mathrm{ha}(\$ 12 / \mathrm{ac})$. Potassium $\left(\right.$ as $\left.\mathrm{K}_{2} \mathrm{O}\right)$ was applied at a rate of $45 \mathrm{~kg} / \mathrm{ha}(40 \mathrm{lb} / \mathrm{ac})$ and costs $\$ 0.51 / \mathrm{kg}(\$ 0.23 / \mathrm{lb})$, for a total cost of $\$ 23 / \mathrm{ha}$ $(\$ 9.08 / \mathrm{ac})$. Lime was applied at a rate of $2.24 \mathrm{Mg} / \mathrm{ha}(1 \mathrm{ton} / \mathrm{ac})$ every three years, or an average annual rate of $0.75 \mathrm{Mg} /$ ha $(0.33$ tons $/ \mathrm{ac})$. At a cost of $\$ 25.35 / \mathrm{Mg}$ ( $\$ 23.00 /$ dry ton) annual lime cost was $\$ 18.91 /$ ha $(\$ 7.66 /$ ac). We assume that application costs were included in the price of the fertilizers and lime. Total variable costs before interest on variable costs was $\$ 195 / \mathrm{ha}(\$ 78.74 / \mathrm{ac})$. At a simple interest rate of $6 \%$ for six months (or 3\%), interest on variable costs was $\$ 5.84 /$ ha $(\$ 2.36 / \mathrm{ac}$ ). Total variable costs were $\$ 200 /$ ha $(\$ 81.10 / \mathrm{ac})$.

\subsubsection{Harvest (machinery) costs}

There were two separate harvesting operations, 1) mowing and 2) pickup and transport to field edge. To calculate machinery costs, first calculate hourly costs for each implement used in these operations 
(Table 6.2), the performance (area covered per hour) in each of these operations, and costs per dry $\mathrm{Mg}$ (dry ton).

Table 6.2. Hourly costs of implements used in silage harvest example

\begin{tabular}{|c|c|c|c|c|c|c|c|c|c|c|c|c|}
\hline & $\begin{array}{l}\text { List } \\
\text { price } \\
(\$)\end{array}$ & $\begin{array}{l}\text { Useful } \\
\text { life } \\
\text { (h) }\end{array}$ & $\begin{array}{c}\text { Annual } \\
\text { use } \\
\text { (h) }\end{array}$ & \begin{tabular}{|c} 
Repairs \\
(fraction \\
list \\
price)
\end{tabular} & $\begin{array}{c}\text { Salvage value } \\
\text { (fraction } \\
\text { purch. price) }\end{array}$ & $\begin{array}{c}\text { Capital } \\
(\$ / \mathbf{h})\end{array}$ & $\begin{array}{l}\text { Repairs } \\
\text { (\$/h) }\end{array}$ & $\begin{array}{c}\text { Fuel } \\
\text { lube } \\
\text { oil } \\
(\$ / \mathbf{h})\end{array}$ & $\begin{array}{c}\text { Insurance } \\
\text { housing } \\
\text { taxes } \\
(\$ / h)\end{array}$ & \begin{tabular}{|c|} 
Interest \\
on \\
variable \\
costs \\
$(\$ / \mathbf{h})$ \\
\end{tabular} & $\begin{array}{c}\text { Labor } \\
(\$ / \mathbf{h})\end{array}$ & $\begin{array}{l}\text { Total } \\
\text { (\$/h) }\end{array}$ \\
\hline Tractor $^{\mathrm{a}}$ & 82,222 & 12,000 & 800 & 1 & 0.283 & 9.90 & 7.54 & 16.16 & 1.34 & 0.75 & 15.93 & 51.62 \\
\hline $\begin{array}{l}\text { Mower- } \\
\text { conditioner }\end{array}$ & 29,111 & 2,500 & 300 & 0.8 & 0.317 & 11.81 & 9.32 & & 1.18 & 0.32 & & 22.63 \\
\hline $\begin{array}{l}\text { Forage } \\
\text { harvester }\end{array}$ & 26,665 & 2,500 & 300 & 0.65 & 0.279 & 11.02 & 6.93 & & 1.05 & 0.24 & & 19.24 \\
\hline $\begin{array}{l}\text { Windrow } \\
\text { pickup head }\end{array}$ & 4,800 & 1,000 & 300 & 0.8 & 0.391 & 3.46 & 3.84 & & 0.21 & 0.12 & & 7.63 \\
\hline $\begin{array}{l}\text { High dump } \\
\text { forage } \\
\text { wagon }\end{array}$ & 25,021 & 2,000 & 300 & 0.5 & 0.431 & 10.91 & 6.26 & & 1.11 & 0.22 & & 18.50 \\
\hline
\end{tabular}

The details of calculations to determine hourly machinery costs for each implement are shown below The interest rate for this example was $6 \%$.

Hourly cost of the $\mathbf{8 9 . 5} \mathbf{~ k W}(\mathbf{1 2 0} \mathbf{~ h p ) ~ t r a c t o r . ~ T h e ~ t r a c t o r ~ l i s t ~ p r i c e ~ w a s ~ a s s u m e d ~ t o ~ b e ~} \$ 82,222$. Therefore, the purchase price, $90 \%$ of list price was $\$ 74,000$. The lifetime was assumed to be 12,000 hours with annual use of 800 hours. The salvage value of was calculated by multiplying the list price by the remaining value calculated by equation $2-4$ with $\mathrm{c}_{1}=0.942, \mathrm{c}_{2}=0.100, \mathrm{c}_{3}=0.0008$ from Table $2.3 ; \mathrm{h}_{\mathrm{a}}$ $=800 \mathrm{~h} ;$ and $\mathrm{n}=12,000 \mathrm{~h}$ of life $/(800 \mathrm{~h} / \mathrm{yr})=15$ years below:

$$
\mathrm{RV}_{\mathrm{n}}=100\left(\mathrm{C}_{1}-\mathrm{C}_{2} \mathrm{n}^{0.5}-\mathrm{C}_{3} \mathrm{~h}_{\mathrm{a}}{ }^{0.5}\right)^{2}=100\left(0.942-(0.1)\left(15^{0.5}\right)-(0.0008)\left(800^{0.5}\right)\right)^{2}=28.3 \%
$$

The salvage value was $\$ 23,269(\$ 82,222 * 0.283)$. The discounted salvage value, calculate by equation $2-2$, at the end of the machine's 15 year life was $\$ 9,709\left(\$ 23,269 / 1.06^{15}\right)$.

The capital cost was calculated by equation 2-3 below. The 1.1 factor accounts for the fact that a powered implement is assumed to operate $10 \%$ more than the implement it powers

$$
C_{o}=1.1\left(\frac{(P P-d S V) * \frac{i}{1-(1+i)^{-n}}+d S V^{*} i}{h_{a}}\right)=1.1\left(\frac{(\$ 74,000-\$ 9,709) * \frac{0.06}{1-(1+0.06)^{-15}}+(\$ 9,709)(0.06)}{800}\right)=\underline{\$ 9.90 / \text { hour }}
$$

The cost of repairs was $\$ 7.54 / \mathrm{h}(1.1 * \$ 82,222 * 1 / 12,000)$. Tractor diesel use was $19.9 \mathrm{~L} / \mathrm{h}$ $(0.22265 * 89.5 \mathrm{~kW})$, or 5.26 gallons $/ \mathrm{h}$. The cost of fuel, lube, and oil was $\$ 16.16 / \mathrm{h}$

$(1.1 *(1.15 * \$ 0.642 / \mathrm{L} * 19.9 \mathrm{~L} / \mathrm{h}))$. Note that the 1.15 accounts for lube and oil being $15 \%$ of fuel costs. The cost of insurance, housing, and taxes was $\$ 1.34 / \mathrm{h}(1.1 *(0.02 *(\$ 74,000+\$ 23,277) / 2) / 800 \mathrm{~h})$. Operating interest was calculated based on 6 months of interest $(6 \% / 2)$ on variable costs: repairs, fuel, lube, and oil; and insurance, housing, and taxes as $\$ 0.75 / \mathrm{h}(0.03 *(\$ 7.54 / \mathrm{h}+\$ 16.16 / \mathrm{h}+\$ 1.34 / \mathrm{h})$. The labor cost was $\$ 15.93 / \mathrm{h}(1.2 * \$ 10.21 / \mathrm{h} * 1.3)$. The 1.3 factor accounts for fringe benefits of $30 \%$ and the 
1.2 accounts for $20 \%$ additional labor over the amount of time an implement operates. The total cost of $\$ 51.62 / \mathrm{h}$ was the sum of the hourly capital cost $(\$ 9.90 / \mathrm{h})$; repairs $(\$ 7.54 / \mathrm{h})$; fuel, lube, and oil $(\$ 16.16 / \mathrm{h})$; insurance, housing, and taxes $(\$ 1.34 / \mathrm{h})$; operating interest $(\$ 0.75 / \mathrm{h})$; and labor $(\$ 15.93 / \mathrm{h})$.

Hourly cost for the mower-conditioner. The mower-conditioner list price was assumed to be $\$ 29,111$. Therefore, the purchase price, $90 \%$ of list price, was $\$ 26,200$. The lifetime use was assumed to be 2,500 hours with annual use of 300 hours. The lifetime repair cost was 0.8 of the list price. The salvage value was calculated by multiplying the list price by the remaining value calculated using equation $2-4$ below with $\mathrm{c}_{1}=0.756, \mathrm{c}_{2}=0.067, \mathrm{c}_{3}=0$ from Table $2.3 ; \mathrm{h}_{\mathrm{a}}=300 \mathrm{~h}$; and $\mathrm{n}=2,500 \mathrm{~h}$ of life $/(300 \mathrm{~h} / \mathrm{yr})=8.33$ years.

$$
\mathrm{RV}_{\mathrm{n}}=100\left(\mathrm{c}_{1}-\mathrm{c}_{2} \mathrm{n}^{0.5}-\mathrm{c}_{3} \mathrm{~h}_{\mathrm{a}}{ }^{0.5}\right)^{2}=100\left(0.756-(0.067)\left(8.33^{0.5}\right)\right)^{2}=31.7 \%
$$

The resulting salvage value was $\$ 9,228(\$ 29,111 * 0.317)$. The discounted salvage value, using equation $2-2$, to the end of the 8.33 year life was $\$ 5,680\left(\$ 9,228 / 1.06^{8.33}\right)$.

The capital cost was determined using equation 2-3:

$C_{o}=\frac{(P P-d S V) * \frac{i}{1-(1+i)^{-n}}+d S V^{* i}}{h_{a}}=\frac{(\$ 26,200-\$ 5,680) * \frac{0.06}{1-(1+0.06)^{-8.33}}+\$ 5,680 * 0.06}{300}=\$ 11.81 / \mathrm{h}$

The estimate hourly cost of repairs was $\$ 9.32 / \mathrm{h}(\$ 29,111 * 0.8 / 2,500 \mathrm{~h})$. The costs of insurance, housing, and taxes was $\$ 1.18 / \mathrm{h}((0.02 *(\$ 26,200+\$ 9,228) / 2) / 300 \mathrm{~h})$. Operating interest was calculated based on 6 months of interest $(6 \% / 2)$ on variable costs: repairs and insurance, housing, and taxes as $\$ 0.32 / \mathrm{h}$ $(0.03 *(\$ 9.32 / \mathrm{h}+\$ 1.18 / \mathrm{h}))$. The total cost of $\$ 22.63 / \mathrm{h}$ was calculated as the sum of the hourly capital $(\$ 11.81 / \mathrm{h})$; repairs $(\$ 9.32 / \mathrm{h})$; insurance, housing, and taxes $(\$ 1.18 / \mathrm{h})$; and operating interest $(\$ 0.32 / \mathrm{h})$.

Hourly cost of pull-type forage harvester. The list price of the forage harvester was assumed to be $\$ 26,665$. Therefore the purchase price, $90 \%$ of list price, was $\$ 23,999$. The lifetime was assumed to be 2,500 hours with annual use of 300 hours. The repair cost was 0.65 of the list price. The salvage value was the list price multiplied by the remaining value calculated by equation $2-4$ with $\mathrm{c}_{1}=0.791, \mathrm{c}_{2}=$ $0.091, \mathrm{c}_{3}=0$ from Table $2.3 ; \mathrm{h}_{\mathrm{a}}=300 \mathrm{~h}$; and $\mathrm{n}=2,500 \mathrm{~h}$ of life $/(300 \mathrm{~h} / \mathrm{yr})=8.33$ years.

$$
\mathrm{RV}_{\mathrm{n}}=100\left(\mathrm{c}_{1}-\mathrm{c}_{2} \mathrm{n}^{0.5}-\mathrm{c}_{3} \mathrm{~h}_{\mathrm{a}}{ }^{0.5}\right)^{2}=100\left(0.791-(0.091)\left(8.33^{0.5}\right)\right)^{2}=27.9 \%
$$

The salvage value was $\$ 7,440(\$ 26,665 * 0.279)$, The discounted salvage value, using equation $2-2$, to the end of the 8.33 year life was $\$ 4,579\left(\$ 7.440 / 1.06^{8.33}\right)$.

The capital cost was calculated using equation 2-3:

$\mathrm{C}_{\mathrm{o}}=\frac{(\mathrm{PP}-\mathrm{dSV}) * \frac{\mathrm{i}}{1-(1+\mathrm{i})^{-\mathrm{n}}}+\mathrm{dSV} * \mathrm{i}}{\mathrm{h}_{\mathrm{a}}}=\frac{(\$ 23,999-\$ 4,579) * \frac{0.06}{1-(1+0.06)^{-8.33}}+\$ 4,579 * 0.06}{300}=\$ 11.02 / \mathrm{h}$

The hourly cost of repairs was $\$ 6.93 / \mathrm{h}\left(\$ 26,665^{*} 0.65 / 2,500 \mathrm{~h}\right)$. The cost of insurance, housing, and taxes was $\$ 1.05 / \mathrm{h}((0.02 *(\$ 23,999+\$ 7,440) / 2) / 300 \mathrm{~h})$. The operating interest was calculated based on 6 months of interest $(6 \% / 2)$ on variable costs: repairs and insurance, housing, and taxes as $\$ 0.24 / \mathrm{h}$ $(0.03 *(\$ 6.93 / \mathrm{h}+\$ 1.05 / \mathrm{h}))$. The total cost of $\$ 19.24 / \mathrm{h}$ was the sum of hourly cost of capital $(\$ 11.02 / \mathrm{h})$; repairs $(\$ 6.93 / \mathrm{h})$; insurance, housing, and taxes $(\$ 1.05 / \mathrm{h})$; and operating interest $(\$ 0.24 / \mathrm{h})$. 
Hourly cost of windrow pickup head for the pull-type forage harvester. The windrow pickup head list price was assumed to be $\$ 4,800$. Therefore, the purchase price, $90 \%$ of list price, was $\$ 4,320$. The lifetime use was assumed to be 1,000 hours with annual use of 300 hours. The lifetime repair cost was 0.8 of the list price. The salvage value was calculated by multiplying the list price by the remaining value fraction calculated using equation 2-4 with $\mathrm{c}_{1}=0.791, \mathrm{c}_{2}=0.091, \mathrm{c}_{3}=0$ from Table $2.3 ; \mathrm{h}_{\mathrm{a}}=300 \mathrm{~h}$; and $\mathrm{n}$ $=1,000 \mathrm{~h}$ of $l i f e /(300 \mathrm{~h} / \mathrm{yr})=3.33$ years

$$
R V_{n}=100\left(c_{1}-c_{2} n^{0.5}-c_{3} h_{a}^{0.5}\right)^{2}=100\left(0.791-(0.091)\left(3.33^{0.5}\right)\right)^{2}=39.1 \%
$$

The salvage value was $\$ 1,877(\$ 4,800 * 0.390)$. The discounted salvage value, using equation $2-2$, to the end of the 3.33 year life was $\$ 1,546\left(\$ 1,877 / 1.06^{3.33}\right)$.

The hourly capital cost was determined using equation 2-3:

$$
C_{o}=\frac{(P P-d S V) * \frac{i}{1-(1+i)^{-n}}+d S V^{*} i}{h_{a}}=\frac{(\$ 4,320-\$ 1,546) * \frac{0.06}{1-(1+0.06)^{-8.33}}+\$ 1,546 * 0.06}{300}=\$ 3.46 / \mathrm{h}
$$

The hourly cost of repairs was $\$ 3.84 / \mathrm{h}(\$ 4,800 * 0.8 / 1,000 \mathrm{~h})$, The cost of insurance, housing, and taxes was $\$ 0.21 / \mathrm{h}(([(0.02 *(\$ 4,320+\$ 1,877) / 2) / 300 \mathrm{~h})$, The cost of operating interest was calculated based on 6 months of interest $(6 \% / 2)$ on variable costs: repairs and insurance, housing, and taxes as $\$ 0.12 / \mathrm{h}$ $(0.03 *(\$ 3.84 / \mathrm{h}+\$ 0.21 / \mathrm{h}))$. The total cost of $\$ 7.63 / \mathrm{h}$ was the sum of hourly cost of capital $(\$ 3.46 / \mathrm{h})$; repairs $(\$ 3.84 / \mathrm{h})$; insurance, housing, and taxes $(\$ 0.21 / \mathrm{h})$; and operating interest $(\$ 0.12 / \mathrm{h})$.

Hourly cost of high dump forage wagon with a roof. The list price of the forge wagon was assumed to be $\$ 25,021$. Therefore, the purchase price was $\$ 22,519$ ( $90 \%$ of list price). The lifetime was assumed to be 2,000 hours with annual use of 300 hours. The lifetime repair cost was $1 / 2$ of the list price. The salvage value was calculated by multiplying the list price by the remaining value fraction calculated by equation $2-4$ with $\mathrm{c}_{1}=0.943, \mathrm{c}_{2}=0.111, \mathrm{c}_{3}=0$ from Table $2.3 ; \mathrm{h}_{\mathrm{a}}=300 \mathrm{~h}$; and $\mathrm{n}=2,000 \mathrm{~h}$ of life $/(300 \mathrm{~h} / \mathrm{yr})=$ 6.67 years.

$$
\mathrm{RV}_{\mathrm{n}}=100\left(\mathrm{c}_{1}-\mathrm{c}_{2} \mathrm{n}^{0.5}-\mathrm{c}_{3} \mathrm{~h}_{\mathrm{a}}^{0.5}\right)^{2}=100\left(0.943-(0.111)\left(6.67^{0.5}\right)\right)^{2}=43.1 \%
$$

The salvage value was $\$ 10,784(\$ 25,021 * 0.431)$. The discounted salvage value, using equation $2-2$, to the end of the 6.67 year life was $\$ 7,311\left(\$ 10,784 / 1.06^{6.67}\right)$.

The capital cost was determined using equation 2-3:

$\mathrm{C}_{\mathrm{o}}=\frac{(\mathrm{PP}-\mathrm{dSV}) * \frac{\mathrm{i}}{1-(1+\mathrm{i})^{-\mathrm{n}}}+\mathrm{dSV} * \mathrm{i}}{\mathrm{h}_{\mathrm{a}}}=\frac{(\$ 22,519-\$ 10,784) * \frac{0.06}{1-(1+0.06)^{-6.67}}+\$ 10,784 * 0.06}{300}=\$ 10.91 / \mathrm{h}$

The cost of repairs, on an hourly basis, was $\$ 6.26 / \mathrm{h}\left(\$ 25,021^{*} 0.5 / 2,000 \mathrm{~h}\right)$. The cost of insurance, housing, and taxes was $\$ 1.11 / \mathrm{h}((0.02 *(\$ 22,519+\$ 10,784) / 2) / 300 \mathrm{~h})$. The operating interest was calculated based on 6 months of interest $(6 \% / 2)$ on variable costs: repairs and insurance, housing, and taxes as $\$ 0.22 / \mathrm{h}(0.03 *(\$ 6.26 / \mathrm{h}+\$ 1.11 / \mathrm{h}))$. The total cost of $\$ 18.50 / \mathrm{h}$ was the sum of hourly costs of capital $(\$ 10.91 / \mathrm{h})$; repairs $(\$ 6.26 / \mathrm{h})$; insurance, housing, and taxes $(\$ 1.11 / \mathrm{h})$; and operating interest $(\$ 0.22 / \mathrm{h})$. 


\subsubsection{A static model of machinery performance}

In a static model no attempt is made to optimize the use of field equipment (operating speed, hours of annual use, and numbers of equipment). Rather, fixed parameter values for speed, hours of use, and field efficiency are assumed. This section describes the application of the costing methodology outlined in this report to evaluate a biomass harvesting operation. [Sokhansanj et al. (2008) provide examples using a model that optimizes hours of equipment use based on cost and machinery performance.] To determine the performance (field area covered per unit of time) of mowing, handling and transport to the field edge operations, estimates of the width, speed, and field efficiency of the mower and windrow pickup head are needed. The combined pickup and transport to the field edge operation consists of two parts, pickup and transport. So the time required for this combined operation is the sum of the time to pickup a wagon load of biomass and the time to transport that wagon load to the field edge, dump the load, and return to the pickup operation.

The mower-conditioner has a width of $4.57 \mathrm{~m}(15 \mathrm{ft})$, a forward speed of $8.05 \mathrm{~km} / \mathrm{h}(5 \mathrm{mi} / \mathrm{h})$, and a field efficiency of 0.8 . The performance of the mower-conditioner, $\mathrm{P}_{\mathrm{mc}}$, can be calculated by:

$$
\begin{aligned}
& \text { SI : } \quad \mathrm{P}_{\mathrm{mc}}=\frac{4.57 \mathrm{~m} * 8.05 \mathrm{~km} / \mathrm{h} * 1000 \mathrm{~m} / \mathrm{km}}{10,000 \mathrm{~m}^{2} / \mathrm{ha}}(0.8)=2.94 \mathrm{ha} / \mathrm{h} \\
& \text { English : } \quad \mathrm{P}_{\mathrm{mc}}=\frac{15 \mathrm{ft} * 5 \mathrm{mi} / \mathrm{h} * 5280 \mathrm{ft} / \mathrm{mi}}{43,560 \mathrm{ft}^{2} / \mathrm{ac}}(0.8)=7.27 \mathrm{ac} / \mathrm{h}
\end{aligned}
$$

Note that in the SI (English) equation above, $10,000 \mathrm{~m}^{2} /$ ha divided $1000 \mathrm{~m} / \mathrm{km}$ by gives the factor of 10 $\left(43,560 \mathrm{ft}^{2} / \mathrm{ac}\right.$ divided by $5280 \mathrm{ft} / \mathrm{mi}$ gives the factor of 8.25$)$ as in equation $4-1$.

The windrow pickup head is only $2.5 \mathrm{~m}(8 \mathrm{ft})$ wide, but the mower-conditioner puts the biomass into a windrow of less than $2.5 \mathrm{~m}$, so the effective operating width of the windrow pickup head is $4.57 \mathrm{~m} \mathrm{(15 \textrm {ft } )}$ [i.e. it picks up the biomass that was grown on a $4.57 \mathrm{~m}(15 \mathrm{ft})$ wide swath on each pass]. The windrow pickup head operates at a speed of $4.83 \mathrm{~km} / \mathrm{h}(3 \mathrm{mi} / \mathrm{h})$ and a field efficiency of 0.7 . The performance of the windrow pickup head is:

$$
\begin{aligned}
& \text { SI : } \quad P_{m c}=\frac{4.57 \mathrm{~m}^{*} 4.83 \mathrm{~km} \mathrm{~h}^{-1} * 1000 \mathrm{~m} \mathrm{~km}^{-1}}{10,000 \mathrm{~m}^{2} \mathrm{ha}^{-1}}(0.7)=1.55 \mathrm{ha} \mathrm{h}^{-1} \\
& \text { English : } \mathrm{P}_{\mathrm{mc}}=\frac{15 \mathrm{ft} * 3 \mathrm{mi} \mathrm{h}^{-1} * 5280 \mathrm{ft} \mathrm{mi}^{-1}}{43,560 \mathrm{ft}^{2} \mathrm{ac}^{-1}}(0.7)=3.82 \mathrm{ac} \mathrm{h}^{-1}
\end{aligned}
$$

The parameters and coverage for the mowing and pickup operations are summarized in Table6.3.

Table 6.3. Performance of mowing and pickup operations for silage harvest example

\begin{tabular}{|l|c|c|c|c|c|c|c|}
\hline \multicolumn{1}{|c|}{ Implement } & \multicolumn{2}{c|}{ Width } & \multicolumn{2}{c|}{ Speed } & \multirow{2}{*}{ Field efficiency } & \multicolumn{2}{c|}{ Coverage } \\
\cline { 1 - 3 } & $\mathbf{f t}$ & $\mathbf{m}$ & $\mathbf{m i} / \mathbf{h}$ & $\mathbf{~ k m} / \mathbf{h}$ & & ac/h & $\mathbf{h a} / \mathbf{h}$ \\
\hline Mower-conditioner & 15 & 4.57 & 5 & 8.05 & 0.8 & 7.27 & 2.94 \\
\hline Windrow pickup head & 15 & 4.57 & 3 & 4.83 & 0.7 & 3.82 & 1.55 \\
\hline
\end{tabular}

When the tractor with the forage harvester and windrow pickup head and high dump forage wagon are used, they engage in two operations: 1) picking up the biomass and 2) moving it to the field edge, dumping the biomass, and returning. It is assumed that the portion of the second operation to 
transport the biomass to the field edge, dump it in the truck trailer, and return to its pickup operation takes $0.167 \mathrm{~h}$ (10 minutes). To pickup the biomass in one wagon load takes $0.142 \mathrm{~h}$ as shown below:

$$
\begin{aligned}
& \text { SI : } \quad \mathrm{t}_{\mathrm{pu}}=\frac{1.98 \frac{\text { dry Mg }}{\text { load }}}{9^{\text {dry Mg} / \mathrm{ha}} * 1.55 \mathrm{ha} / \mathrm{h}}=0.142 \mathrm{~h} / \mathrm{load} \\
& \text { English : } \mathrm{t}_{\mathrm{pu}}=\frac{2.185 \frac{\text { dry tons }}{\text { load }}}{4.02^{\text {dry tons } / \mathrm{ac}} * 3.82 \mathrm{ac} / \mathrm{h}}=0.142 \mathrm{~h} / \mathrm{load}
\end{aligned}
$$

The total pickup and transport time is $0.309 \mathrm{~h}(0.142 \mathrm{~h}+0.167 \mathrm{~h})$. The total biomass picked up and moved to the field edge is:

$$
\begin{aligned}
& \text { SI : } \quad \mathrm{W}_{\text {load }}=\frac{1.98^{\mathrm{dry} \mathrm{Mg} / \text { load }}}{0.309 \mathrm{~h} / \text { load }}=6.41^{\mathrm{dry} \mathrm{Mg} / \mathrm{h}} \\
& \text { English : } \quad \mathrm{W}_{\text {load }}=\frac{2.185^{\mathrm{dry} \text { tons } / \text { load }}}{0.309 \mathrm{~h} / \mathrm{load}}=7.07^{\mathrm{dry} \text { tons } / \mathrm{h}}
\end{aligned}
$$

The area covered in the combined pickup and transport operation is:

$$
\begin{aligned}
& \text { SI : } \quad \mathrm{A}_{\text {load }}=\frac{6.41^{\mathrm{dry} \mathrm{Mg} / \mathrm{h}}}{9^{\mathrm{dry} \mathrm{Mg} / \mathrm{ha}}}=0.712^{\mathrm{ha} / \mathrm{h}} \\
& \text { English : } \quad \mathrm{A}_{\text {load }}=\frac{7.07^{\text {dry tons } / \mathrm{h}}}{4.02^{\text {dry tons } / \mathrm{ac}}}=1.76 \mathrm{ac} / \mathrm{h}
\end{aligned}
$$

The parameters and coverage of the combined pickup and loading operations are summarized in Table 6.4 .

Table 6.4. Performance of the combined pickup and transport to field edge operation in silage harvest example

\begin{tabular}{|l|c|c|c|c|}
\hline Parameter & \multicolumn{2}{|c|}{ English units } & \multicolumn{2}{c|}{ SI units } \\
\hline High dump forage wagon load & dry ton & 2.185 & dry Mg & 1.98 \\
\hline Yield & dry ton/ac & 4.02 & dry Mg/ha & 9 \\
\hline Pickup time & $\mathrm{h}$ & 0.142 & $\mathrm{~h}$ & 0.142 \\
\hline Travel time & $\mathrm{h}$ & 0.167 & $\mathrm{~h}$ & 0.167 \\
\hline Total pickup and transport time & $\mathrm{h}$ & 0.309 & $\mathrm{~h}$ & 0.309 \\
\hline Quantity harvested/moved & dry ton $/ \mathrm{h}$ & 7.07 & $\mathrm{dry} \mathrm{Mg} / \mathrm{h}$ & 6.41 \\
\hline Area harvested & $\mathrm{ac} / \mathrm{h}$ & 1.76 & $\mathrm{ha} / \mathrm{h}$ & 0.712 \\
\hline
\end{tabular}

\subsubsection{Harvest costs}

Harvest costs are the sum of the mowing plus the combined pickup and transport to the field edge operations. Mowing costs were $\$ 74.25 / \mathrm{h}$ (tractor $\$ 51.62 / \mathrm{h}+$ mower-conditioner $\$ 22.63 / \mathrm{h}$ ). Costs per unit area were $\$ 25.26 / \mathrm{ha}(\$ 10.21 / \mathrm{ac})$ based on the mowing operation performance rate of $2.94 \mathrm{ha} / \mathrm{h}(7.27$ 
$\mathrm{ac} / \mathrm{h})$. At a yield of 9 dry $\mathrm{Mg} / \mathrm{ha}$ (4.02 dry tons/ac) mowing cost was $\$ 2.81 / \mathrm{dry} \mathrm{Mg}(\$ 2.54 / \mathrm{dry}$ ton). The combined pickup and transport to the field edge costs were $\$ 96.99 / \mathrm{h}$ (tractor $\$ 51.62 / \mathrm{h}+$ forage harvester $\$ 19.24 / \mathrm{h}+$ windrow pickup head $\$ 7.63 / \mathrm{h}+$ high dump forage wagon $\$ 18.50 / \mathrm{h}$ ). Costs per unit area were $\$ 136.22 / \mathrm{ha}(\$ 55.11 / \mathrm{ac})$ based on the pickup and transport to field edge operation performance rate of $0.712 \mathrm{ha} / \mathrm{h}(1.76 \mathrm{ac} / \mathrm{h})$. At a yield of $9 \mathrm{dry} \mathrm{Mg} / \mathrm{ha}$ (4.02 dry tons/ac) pickup and transport to field edge cost was $\$ 15.14 /$ dry $\mathrm{Mg}(\$ 13.71 /$ dry ton). Total harvest cost (mowing plus pickup and transport) was $\$ 17.95 /$ dry $\operatorname{Mg}(\$ 16.25 /$ dry ton) (Table 6.5).

Table 6.5. Harvest costs for [tall fescue] silage harvest example

\begin{tabular}{|l|c|c|c|c|c|c|c|}
\hline Implement & Cost & \multicolumn{2}{|c|}{ Coverage } & \multicolumn{5}{|c|}{ Cost $^{\text {a }}$} \\
\hline & $\mathbf{\$} / \mathbf{h}$ & $\mathbf{a c} / \mathbf{h}$ & $\mathbf{h a} / \mathbf{h}$ & $\mathbf{\$} / \mathbf{a c}$ & $\mathbf{\$} / \mathbf{h a}$ & $\mathbf{\$} / \mathbf{d r y}$ ton & \$/dry Mg \\
\hline Tractor & 51.62 & & & & & & \\
\hline Mower-conditioner & 22.63 & & & & & & \\
\hline Subtotal-mow-condition & 74.25 & 7.27 & 2.94 & 10.21 & 25.26 & 2.54 & 2.81 \\
\hline Tractor & 51.62 & & & & & & \\
\hline Forage harvester & 19.24 & & & & & & \\
\hline Windrow pickup head & 7.63 & & & & & & \\
\hline High dump forage wagon & 18.50 & & & & & & \\
\hline Subtotal-pickup and transport to field edge & 96.99 & 1.76 & 0.712 & 55.11 & 136.22 & 13.71 & 15.14 \\
\hline Total & & & & $\mathbf{6 5 . 3 2}$ & $\mathbf{1 6 1 . 4 4}$ & $\mathbf{1 6 . 2 5}$ & $\mathbf{1 7 . 9 5}$ \\
\hline${ }^{a}$ Yield 9 dry Mg/ha (4.02 dry tons/ac) & & & & & \\
\hline
\end{tabular}

\subsubsection{Fixed costs}

Fixed costs for machinery are already included in the harvest costs. Additional fixed costs that should be included are land rent [\$61.75/ha (\$25/ac) assumed for this example] and overhead [\$32.11/ha (\$13/ac)] which total to $\$ 93.86 /$ ha $(\$ 38.00 / a c)$.

\subsubsection{Total costs of in-field production}

Total costs of production are $\$ 455.83 / \mathrm{ha}(\$ 184.42 / \mathrm{ac})$ consisting of variable costs of $\$ 200.49 / \mathrm{ha}$ (\$81.49/ac), harvest costs of $\$ 161.48 / \mathrm{ha}(\$ 65.32 / \mathrm{ac})$, and fixed costs of $\$ 93.86 / \mathrm{ha}(\$ 38.00 / \mathrm{ac})$. Based on a yield of 9 dry $\mathrm{Mg} / \mathrm{ha}$ (4.02 dry tons/ac) unit costs of the tall fescue production are $\$ 50.65 / \mathrm{dry} \mathrm{Mg}$ (\$45.91/dry ton) (Table 6.1).

\subsection{STORAGE OF BALED BIOMASS}

This example compares storage costs for 100 dry $\mathrm{Mg}$ (110 dry tons) of large square switchgrass bales $(1.22 \mathrm{~m} \mathrm{x} 1.22 \mathrm{~m} 2.44 \mathrm{~m} ; 4 \mathrm{ft} \times 4 \mathrm{ft} \times 8 \mathrm{ft})$. Each bale weighs approximately $0.54 \mathrm{Mg}(1,200 \mathrm{lb})$, on a wet basis. Bales are stored 1) outside, unprotected (only appropriate in some regions due to excessive losses in humid environments); 2) on a gravel pad, covered with a tarp; and 3) indoors. It was assumed that moisture content was $15 \%$ (wet basis). The biomass storage location was best described as cropland. 


\subsubsection{Determining required storage area}

If each bale weighs $0.54 \mathrm{Mg}(1,200 \mathrm{lb})$, there will be 216 bales to be stored. The bales were assumed to be placed in a stack 6 bales wide, 4 bales high and 9 bales long. Thus, the stack footprint is $160.5 \mathrm{~m}^{2}$ $\left(1,728 \mathrm{ft}^{2}\right)$. Total land area assigned to storage was $0.40 \mathrm{ha}\left(4,000 \mathrm{~m}^{2}\right)$ [1 acre $\left.\left(43,560 \mathrm{ft}^{2}\right)\right]$ to allow space for maneuvering large equipment and trucks and adequate separation from adjacent facilities.

\subsubsection{Costs of storing bales on ground unprotected}

The only cost for storing bales unprotected on the ground is the cost of land at $\$ 210$ per hectare ( $\$ 85 /$ acre). Adjusting for moisture content, the cost per dry Mg of switchgrass was $\$ 0.84 / \mathrm{dry} \mathrm{Mg}$ $(\$ 210 * 0.4 \mathrm{ha} / 100$ dry $\mathrm{Mg}$ ) or $\$ 0.77 /$ dry ton $(\$ 85 * 1$ acre/110 dry ton). It was assumed that losses of switchgrass during storage were similar to hay losses. Thus, from Table 5.1, the annual storage loss was estimated to be $25 \%$. The costs of storing biomass outside, unprotected, $\mathrm{C}_{\mathrm{o} \_ \text {ground, }}$, can be adjusted for losses using equation 5.2.

$$
\begin{aligned}
& \text { SI : } \quad \mathrm{C}_{\mathrm{o}_{-} \text {ground }}=\frac{\$ 0.84}{\operatorname{dry} \mathrm{Mg}}\left(\frac{1}{1-0.25}\right)=\$ 1.12 / \text { dry } \mathrm{Mg} \\
& \text { English : } \mathrm{C}_{\mathrm{o}_{-} \text {ground }}=\frac{\$ 0.77}{\operatorname{dry} \operatorname{ton}}\left(\frac{1}{1-0.25}\right)=\$ 1.03 / \text { dry ton }
\end{aligned}
$$

\subsubsection{Costs for storing bales outside on gravel pad, covered with tarp}

The costs for storing biomass on a gravel pad and covered with a tarp were land, site preparation, tarp, and labor to place and remove the tarp each year.

Tarp. To calculate the tarp cost, the size of the tarp must first be determined. The tarp was sized to cover the top and all sides of the stack. The stack is $7.32 \mathrm{~m}$ wide (6 bales*1.22 m), $4.88 \mathrm{~m}$ tall (4*1.22), and $22.0 \mathrm{~m}$ long $\left(9^{*} 2.44 \mathrm{~m}\right)(24 \mathrm{ft} \times 16 \mathrm{ft} \times 72 \mathrm{ft})$. The tarp area required was $446 \mathrm{~m}^{2}\left(4,800 \mathrm{ft}^{2}\right)$. The estimated tarp cost (using data provided in Table 5.2), was $\$ 1,298\left(446 \mathrm{~m}^{2} * \$ 2.91 / \mathrm{m}^{2}\right)$. The tarp was estimated to have a useful life of 5 years (Table 5.2). Therefore, the annual ownership cost of the tarp, using the capital recovery method (equation 5-1) was:

$$
\mathrm{C}_{\mathrm{o}_{-} \operatorname{tarp}}=(\$ 1,298)\left(\frac{0.06}{1-(1+0.06)^{-5}}\right)=\$ 308
$$

Labor to place and remove the tarp each year is $\$ 241\left(\$ 0.54 / \mathrm{m}^{2} * 446 \mathrm{~m}^{2}\right)$.

Gravel pad. The gravel pad was sized for the stack footprint of $161 \mathrm{~m}^{2}\left(1,728 \mathrm{ft}^{2}\right)$ as calculated in Section 6.2.1 plus an additional $1 \mathrm{~m}(3.3 \mathrm{ft})$ of clearance on all sides of the stack for a total area of $223 \mathrm{~m}^{2}$ $\left(2,405 \mathrm{ft}^{2}\right)$. The cost to construct the pad would be approximately $\$ 2,308\left(223 \mathrm{~m}^{2} * \$ 10.33 / \mathrm{m}^{2} ; 2,405 \mathrm{ft}^{2}\right.$ $\left.* \$ 0.96 / \mathrm{ft}^{2}\right)$. The annual ownership cost of the gravel pad with a useful life of 10 years was:

$$
\mathrm{C}_{\text {o_gravel }_{-}}=(\$ 2,308)\left(\frac{0.06}{1-(1+0.06)^{-10}}\right)=\$ 314
$$


Land and other ownership costs. The land cost was the same as for storing bales outside with no protection, $\$ 210$ per hectare or $\$ 1.12 / \mathrm{dry} \mathrm{Mg}$ ( $\$ 1.03 / \mathrm{dry}$ ton). The annual costs of repair and insurance is $\$ 72$, or $2 \%$ of the $\$ 3,606(\$ 1,298+\$ 2,308)$ initial investment.

Total annual cost. The total annual cost of storing biomass on a gravel pad and covered with a tarp which includes the tarp (\$308), gravel pad (\$314), land (\$85), labor (\$241), and insurance and repair (\$72) is $\$ 1,020$. On a mass basis, the cost is $\$ 10.20 / \mathrm{dry} \mathrm{Mg}(\$ 1,020 / 100$ dry $\mathrm{Mg}$ ) or $\$ 9.27 /$ dry ton. If annual storage loss is assumed to be $6 \%$, the adjusted annual cost is $\$ 10.87 / \mathrm{dry} \mathrm{Mg}(\$ 9.86 / \mathrm{dry}$ ton).

\subsubsection{Costs of storing bales indoors}

Building. It was assumed that a pole frame structure with one side open was constructed to store the switchgrass bales. The building cost, from Table 5.2, was $\$ 99.35 / \mathrm{m}^{2}\left(\$ 9.23 / \mathrm{ft}^{2}\right)$. The size of the building was determined using the same procedure as the gravel pad (1 m clearance on all sides of the stack) as $223.4 \mathrm{~m}^{2}\left(2,405 \mathrm{ft}^{2}\right)$. Thus, the construction cost was $\$ 22,155\left(\$ 99.35 / \mathrm{m}^{2} * 223 \mathrm{~m}^{2}\right)$. The annual ownership cost of the building, using the capital recovery method (equation 5-1) was:

$$
\mathrm{C}_{\mathrm{o}_{-} \text {bldg }}=(\$ 22,155)\left(\frac{0.06}{1-(1+0.06)^{-20}}\right)=\$ 1,936
$$

Land and other ownership costs. As in the previous two cases when bales were stored outside, one acre was allotted to the storage area. Thus, land cost was $\$ 85$, or $\$ 1.12 / \mathrm{dry}_{\mathrm{Mg}}{ }^{1}\left(\$ 1.03 / \mathrm{dry} \operatorname{ton}^{1}\right)$. The annual costs of repair and insurance were $\$ 443$, or $2 \%$ of the $\$ 22,155$ initial investment.

Total annual cost. The total annual cost of storing biomass indoors included the building $(\$ 1,936)$, land (\$85), and insurance and repair $(\$ 443)$ is $\$ 2,464$. On a mass basis, the cost was $\$ 24.64 / \mathrm{dry} \mathrm{Mg}$ $(\$ 2,464 / 100$ dry $\mathrm{Mg})$ or $\$ 22.40 /$ dry ton. If annual storage loss was assumed to be $2 \%$, the adjusted annual cost was $\$ 25.20 /$ dry $\mathrm{Mg}(\$ 22.86 /$ dry ton).

Because indoor storage is expensive, it probably only makes sense if more than one set of bales is stored per year (e.g. bales are stored for 6 months and then utilized and then a new group of bales is stored for the remainder of the year). In this scenario, the cost per ton is divided by the total number times bales are stored in a year. This feature is included in IBSAL (Sokhansanj et al. 2008).

\subsubsection{Comparing storage options}

The annualized costs of switchgrass bale storage options evaluated in this section are given in Table 6.6. These costs are adjusted for estimated dry matter loss. Although storing outside, unprotected appears to be the most cost effective storage option based on the cost estimations given in Table 6.1, the potential loss of $25 \%$ of the dry matter is not desirable. However, in the scenario presented here, storing biomass inside a storage building was likely not feasible at $\$ 25.20 / \mathrm{dry} \mathrm{Mg}$. If the lost biomass is valued at $\$ 55.12$ dry MG (\$50/dry ton) then the two outside options have similar costs, while the indoor storage is about twice as expensive. It should be noted that this analysis only considered dry matter loss. There are other potential changes in composition during storage that may affect biomass value. Some changes in the chemical composition of biomass during storage may prove to be advantageous to downstream conversion processes. Further research is needed to better understand these processes before they can be accounted for in economic analyses. 
Table 6.6. Costs of three storage options for switchgrass bales.

\begin{tabular}{|c|c|c|c|c|}
\hline Storage option & $\begin{array}{l}\text { Annual cost } \\
\text { \$/dry Mg } \\
\text { (\$/dry ton) }\end{array}$ & $\begin{array}{c}\text { Losses } \\
\%\end{array}$ & $\begin{array}{c}\text { Value of losses at } \\
\$ 55.12 / \text { dry } \mathbf{M g} \\
\text { (\$50/dry ton) }\end{array}$ & $\begin{array}{l}\text { Total cost } \\
\text { \$/dry Mg } \\
\text { (\$/dry ton) }\end{array}$ \\
\hline Outside, unprotected & $1.12(1.03)$ & 25 & $13.78(12.50)$ & $14.90(13.53)$ \\
\hline Outside, tarped on gravel pad & $10.87(9.86)$ & 6 & $3.31(3.00)$ & $14.18(12.86)$ \\
\hline Inside a storage building & $25.20(22.86)$ & 2 & $1.10(1.00)$ & $26.30(23.86)$ \\
\hline
\end{tabular}

\section{REFERENCES}

AAEA. 2000. Commodity costs and returns estimation handbook: A report of the AAEA Task Force on Commodity Costs and Returns. Available at: http://www.economics.nrcs.usda.gov/care/Aaea/.

ASABE. 2006a. D497.5: Agricultural machinery management data. In ASABE Standards, American Society of Agricultural Engineers, St. Joseph, MI.

ASABE. 2006b. EP496.3: Agricultural machinery management. In ASABE Standards, American Society of Agricultural Engineers, St. Joseph, MI.

ASAE. 2001. D497.4: Agricultural machinery management data. In ASAE Standards, American Society of Agricultural Engineers, St. Joseph, MI.

Brechbill, Sarah C. and Wallace E. Tyner. 2008. The economics of biomass collection, transportation, and supply to Indiana cellulosic and electric utility facilities. Working Paper \#08-03, Dept. of Agricultural Economics, Purdue University, West Lafayette, IN.

Burdine, K. H., D. Overhults and R. Trimble. 2005. The economics of hay storage. University of Kentucky College of Agriculture. Available at: http://www.uky.edu/Ag/AgEcon/pubs/ext_aec/ext2005-01d.html.

Collins, M., D. Dirtsch, J. C. Henning, L. W. Turner, S. Isaacs and G. D. Lacefield. 1997. Round bale hay storage in Kentucky. AGR-171. Kentucky Cooperative Extension Service.

Cross, T. L. and G. M. Perry. 1995. Depreciation patterns for agricultural machinery. American Journal of Agricultural Economics 77: 194-204.

Cross, T. L. and G. M. Perry. 1996. Remaining value functions for farm equipment. Applied Engineering in Agriculture 12: 547-553.

DOE/EIA. 2008. Annual Energy Outlook 2008. DOE/EIA-0383(2008). Energy Information Administration, U.S. Department of Energy, Washington, DC.

Gay, S. W. and R. Grisso. 2002. Planning for a Farm Storage Building. Bulletin 442-760. Virginia Cooperative Extension.

Gempler's. 2008. Heavy-duty hay tarps. Available at: http://www.gemplers.com/shop/tarps-hay.

Holmes, B. 2004. Comparing Round Bale Storage Costs - Spreadsheet. University of Wisconsin Extension. Available at:

http://www.uwex.edu/ces/crops/uwforage/storage.htm\#Storage\%20Sizing\%20and\%20Manageme $\mathrm{nt} \% 20$ (hay).

Huhnke, R. L. 2006. Round bale hay storage. BAE-1716. Oklahoma Extension Service.

Hunt, D. 1995. Farm power and machinery management, 9th edition. Iowa State University Press, Ames, IA.

International Code Council. 2006. International Fire Code. Washington, DC: ICC.

Miller, P. and J. H. Marter. 2003. Bunker silo systems engineered for producer profit. Fifth Interntational Dairy Housing Conference, Fort Worth, TX.

Nebraska Tractor Test Laboratory. 2008. Tractor test reports. Available at: http://tractortestlab.unl.edu/testreports.htm.

Ogershok, D. 2008. National building cost manual, 32 Edition. Craftsman Book Company, Carlsbad, CA

RSMeans. 2007. RSMeans Site Work \& Landscape Cost Data 2008: 27th edition. Reed Construction Data, Inc., Kingston, MA. 
Shinners, K. J., B. N. Binversie, R. E. Muck and P. J. Weimer. 2007. Comparision of wet and dry corn stover harvest and storage. Biomass \& Bioenergy 31: 211-221.

Sokhansanj, S., A. Kumar and A. F. Turhollow. 2006. Development and implementation of integrated biomass supply analysis and logistics model (IBSAL). Biomass \& Bioenergy 30 (10): 838-847.

Sokhansanj, S., A.F. Turhollow, E.G. Wilkerson. 2008. Development of the Integrated Biomass Supply Analysis and Logistics Model (IBSAL). Technical Memorandum ORNL/TM-2006/57. Oak Ridge National Laboratory, Oak Ridge, TN 37831.

Tarps Plus. 2007. Hay tarps. Available at: http://www.tarpsplus.com/haycovers.html.

Turhollow, A. F. and S. Sokhansanj. 2007. Costs of harvesting, storing in a large pile, and transporting Corn Stover in a Wet Form. Applied Engineering in Agriculture 23 (4): 439-448.

USDA/NASS. 2000. Agricultural prices 1999 summary. Available at: http://usda.mannlib.cornell.edu/usda/nass/AgriPricSu//2000s/2004/AgriPricSu-07-24-2000.pdf.

USDA/NASS. 2004a. Agricultural prices 2003 summary. Available at: http://usda.mannlib.cornell.edu/usda/nass/AgriPricSu//2000s/2004/AgriPricSu-07-23-2004.pdf.

USDA/NASS. 2004b. Farm labor. Available at: http://usda.mannlib.cornell.edu/usda/nass/FarmLabo//2000s/2004/FarmLabo-11-19-2004.pdf.

USDA/NASS. 2005. Farm labor. Available at: http://usda.mannlib.cornell.edu/usda/nass/FarmLabo//2000s/2005/FarmLabo-11-18-2005.pdf.

USDA/NASS. 2007a. Farm labor. Available at: http://usda.mannlib.cornell.edu/usda/nass/FarmLabo//2000s/2007/FarmLabo-11-16-2007.pdf.

USDA/NASS. 2007b. Land values and cash rents, 2007 summary. US Department of Agriculture, National Agricultural Statistics Service, Washington, DC. Available at: http://usda.mannlib.cornell.edu/nass/AgriLandVa/2000s/2007/AgriLandVa-08-03-2007.pdf.

USDA/NASS. 2008a. Agricultural prices 2007 summary. Available at: http://usda.mannlib.cornell.edu/usda/nass/AgriPricSu//2000s/2008/AgriPricSu-07-312008_revision.pdf.

USDA/NASS. 2008b. Agricultural prices April 2008. Available at: http://usda.mannlib.cornell.edu/usda/nass/AgriPric//2000s/2008/AgriPric-04-30-2008.pdf.

USDA/NASS. 2008c. Farm labor. Available at: http://usda.mannlib.cornell.edu/MannUsda/viewDocumentInfo.do?documentID=1063.

USDA/NASS. 2009. Agricultural prices Januaryl 2009. Available at: http://usda.mannlib.cornell.edu/usda/nass/AgriPric//2000s/2009/AgriPric-01-30-2009.pdf.

Wilcke, B., G. Cuomo and C. Fox. 1999. Preserving the value of dry stored hay. FO-07404-GO. University of Minnesota Extension. 
Appendix A

PAGE NUMBERS FOR REFERENCES TO OLD AND NEW VERSIONS OF AAEA COST AND COMMODITY RETURNS ESTIMATION HANDBOOK 


\section{APPENDIX A: PAGE NUMBERS FOR REFERENCES TO OLD AND NEW VERSIONS OF AAEA COST AND COMMODITY RETURNS ESTIMATION HANDBOOK}

The AAEA revised its Commodity costs and returns estimation handbook in 2000. We have this as a PDF file and the earlier 1997 version as a printed document. The revisions appear to be minor. However, the pagination between the two versions is slightly different and we list the page numbers referred to in this document from these two versions in the following table.

\begin{tabular}{|c|c|}
\hline Page number from 2000 PDF file & Page number from 1997 printed version \\
\hline $5-30$ & $5-28$ \\
\hline $6-7$ to $6-11$ & $6-7$ to $6-11$ \\
\hline $6-8$ & $6-8$ \\
\hline $6-11$ & $6-11$ \\
\hline $14-11$ & $14-8$ \\
\hline $14-17$ & $14-14$ \\
\hline
\end{tabular}

